\title{
A new freshwater crab of the family Hymenosomatidae MacLeay, 1838 from New Caledonia (Crustacea, Decapoda, Brachyura) and an updated review of the hymenosomatid fauna of New Caledonia
}

\author{
Danièle GUINOT ${ }^{1, *}$ \& Valentin de MAZANCOURT ${ }^{2}$ \\ ${ }^{1}$ ISYEB (CNRS, MNHN, EPHE, Sorbonne Université), Institut Systématique Évolution Biodiversité, \\ Muséum national d'histoire naturelle, case postale 53, 57 rue Cuvier, 75231 Paris cedex 05, France. \\ ${ }^{2}$ Unité Biologie des organismes et écosystèmes aquatiques (BOREA), Muséum national d'histoire \\ naturelle, Sorbonne Université, Université de Caen Normandie, Université des Antilles, CNRS, IRD, \\ CP26, 57 rue Cuvier, 75231 Paris cedex 05, France. \\ ${ }^{2}$ Museum für Naturkunde, Leibniz Institute for Evolution and Biodiversity Science, \\ Invalidenstraße 43, 10115 Berlin. Germany. \\ *Corresponding author: guinot@mnhn.fr \\ ${ }^{2}$ Email: valentin.seizilles-de-mazancourt@edu.mnhn.fr \\ ${ }^{1}$ urn:1sid:zoobank.org:author:40188B9C-03AD-4CD2-8148-11F0A39CE3A2 \\ ${ }^{2}$ urn:1sid:zoobank.org:author:334E54F3-9FE1-4208-8861-1946579697A5
}

\begin{abstract}
A new genus and species, Richerius marqueti gen. et sp. nov., of a crab of the family Hymenosomatidae MacLeay, 1838 are described from the inland waters of New Caledonia based on several specimens collected in two streams at altitudes of $180 \mathrm{~m}$ and $500 \mathrm{~m}$, respectively. Richerius marqueti gen. et sp. nov. was compared to the other freshwater species known in New Caledonia, Odiomaris pilosus (A. Milne-Edwards, 1873), and to species of Amarinus Lucas, 1980, a genus comprising many freshwater species in New Zealand, Australia, Indonesia, the Philippines, and Papua New Guinea, but never recorded in New Caledonia. The barcode fragment of the COI mitochondrial gene was sequenced for seven specimens of $R$. marqueti gen. et sp. nov., and all sequences were deposited in GenBank. A brief and updated review of the New Caledonian marine and freshwater hymenosmatid fauna is provided.
\end{abstract}

Keywords. Richerius marqueti, new genus, new species, New Caledonia, COI.

Guinot D. \& Mazancourt V. de. 2020. A new freshwater crab of the family Hymenosomatidae MacLeay, 1838 (Crustacea, Decapoda, Brachyura) and an updated review of the hymenosomatid fauna of New Caledonia. European Journal of Taxonomy 671: 1-29. https://doi.org/10.5852/ejt.2020.671

\section{Introduction}

Over the last five years, two French expeditions (Hydrobio expeditions), as part of "Our Planet Reviewed", a major exploration program of the natural world that the Muséum national d'histoire naturelle (MNHN) has been leading since 2006, managed to collect a number of specimens belonging 
to the family Hymenosomatidae MacLeay, 1838 from New Caledonia. They were caught in inland freshwaters in the North and South Provinces. To this material were added hymenosomatids obtained separately by some colleagues during previous biodiversity discovery expeditions led by the MNHN.

A hymenosomatid crab from two streams at altitudes of $180 \mathrm{~m}$ and $500 \mathrm{~m}$, respectively, could not be assigned to the well known New Caledonian endemic freshwater species Odiomaris pilosus (A. MilneEdwards, 1873) and appeared new to science. A new genus and a new species, Richerius marqueti gen. et sp. nov., are described within the subfamily Odiomarinae Guinot, 2011, and compared to O. pilosus and to the second species of the genus, O. estuarius Davie \& Richer de Forges, 1996, exclusively brackish. The characters that differentiate Richerius gen. nov. from Amarinus Lucas, 1980, a genus known from the fresh and brackish waters of New Zealand, Australia, Indonesia, the Philippines, and Papua New Guinea, but never from New Caledonia, required a thorough examination. As the genus Amarinus appears to be paraphyletic, including a variable arrangement of the antennule and antenna, we have therefore limited our comparison to the type species, A. lacustris (Chilton, 1882), also freshwater.

\section{Material and methods}

\section{Institutional abbreviations}

MNHN = Muséum national d'histoire naturelle, Paris, France

RMNH = Nationaal Natuurhistorisch Museum (currently Naturalis Biodiversity Center, NBC), Leiden, the Netherlands

ZRC = Zoological Reference Collection of the Lee Kong Chian Natural History Museum (ex Raffles Museum of Biodiversity Research), National University of Singapore, Singapore

\section{Morphological study}

Measurements are provided in millimetres and reported as carapace length $(\mathrm{cl}) \times$ carapace width $(\mathrm{cw})$, respectively. The following abbreviations are used:

$$
\begin{array}{ll}
\mathrm{cl} & =\text { caparace length } \\
\mathrm{cW} & =\text { caparace width } \\
\mathrm{G} 1 & =\text { male first pleopod } \\
\mathrm{G} 2 & =\text { male second pleopod } \\
\mathrm{mxp} 3 & =\text { third maxillipeds } \\
\mathrm{P} 1-\mathrm{P} 5 & =\text { pereiopods } 1-5 \text { (P1: cheliped; P2-P5: walking legs), respectively }
\end{array}
$$

The terminology for carapace regions follows that proposed by Melrose (1975) and Lucas (1980), for the thoracic sternum that proposed by Guinot (2011a, 2011b). The thoracic somites are numbered from 1 to 8 . Thoracic sternal sutures are referred to by the number of the two thoracic sternites involved and are therefore numbered from $1 / 2$ to $7 / 8$.

\section{DNA sequences}

In order to ease future studies, we sequenced the barcode fragment of the COI mitochondrial gene (Folmer et al. 1994) for seven specimens of the new species Richerius marqueti gen. et sp. nov. (Table 1). DNA was extracted from pereiopods using the semi-automatic Eppendorf epMotion 5075 robot. Fragments of the mitochondrial COI $(\sim 600 \mathrm{bp})$ were amplified using the standard Folmer primers (LCO1490: 5'-GGTCAACAAATCATAAAGATATTGG-3'; HCO2198: 5'-TAAACTTCAGGGTGACCAAAAAATCA-3') (Folmer et al. 1994). DNA amplifications were performed in $20 \mu \mathrm{l}$ PCR reactions, containing approximately $3 \mathrm{ng}$ of template DNA, $2.5 \mathrm{mM} \mathrm{MgCl}$, $0.26 \mathrm{mM}$ of each nucleotide, $0.3 \mu \mathrm{M}$ of each primer, $5 \%$ DMSO, $1 \mathrm{ng}$ of BSA and 1.5 units of QBIOTAQ polymerase (MPBiomedicals). Amplification products were generated by an initial denaturation step 
Table 1. Sequences data of Richerius marqueti gen. et sp. nov.

\begin{tabular}{lllc}
\hline Collection number & Type status & Locality & GenBank number \\
\hline MNHN-IU-2014-21500 & Holotype & Boürou & MT364999 \\
MNHN-IU-2014-21501 & Paratype & Böua & MT365001 \\
MNHN-IU-2014-21502 & Paratype & Böua & MT365002 \\
MNHN-IU-2014-21503 & Paratype & Boürou & MT364998 \\
MNHN-IU-2014-21504 & Paratype & Boürou & MT365000 \\
MNHN-IU-2014-21505 & Paratype & Bouïrou & MT364996 \\
MNHN-IU-2014-21506 & Paratype & Boü̈rou & MT364997 \\
\hline
\end{tabular}

of 4 min at $94^{\circ} \mathrm{C}$ followed by 35 cycles of denaturation at $94^{\circ} \mathrm{C}$ for $30 \mathrm{~s}$, annealing at $48^{\circ} \mathrm{C}$ for $40 \mathrm{~s}$, extension at $72^{\circ} \mathrm{C}$ for $60 \mathrm{~s}$ and a final extension step at $72^{\circ} \mathrm{C}$ for $7 \mathrm{~min}$.

PCR products were sequenced using the same primers and in both directions to ensure the accuracy of base calls. Chromatograms were edited using Geneious ver. 8 software (http://www.geneious.com/ Kearse et al. 2012). All sequences were deposited in GenBank (Table 1).

\title{
Results
}

\section{Taxonomy account}

\author{
Infraorder Brachyura Latreille, 1802 \\ Subsection Heterotremata Guinot, 1977 \\ Superfamily Hymenosomatoidea MacLeay, 1838 \\ Family Hymenosomatidae MacLeay, 1838 \\ Subfamily Odiomarinae Guinot, 2011 \\ Genus Richerius gen. nov. \\ urn:lsid:zoobank.org:act:5B6DC66F-A878-4511-8CF5-06DD245F1896
}

\section{Type species}

Richerius marqueti sp. nov. by present designation.

\section{Diagnosis}

Carapace circular to oval, width only slightly exceeding length; dorsal carapace surface not strongly outlined by grooves; only gastrocardiac and thoracic grooves well defined, not reaching antero- and posterolateral margins; carapace rim continuous across behind rostrum. Rostrum broadly rounded, spade-shaped, slightly deflexed but not ending in narrow triangular tip extending between antennules. Proepistome represented by ventral expansion of rostrum (and not rostrum itself). Antennules obliquely folded along hollowed ventral parts of rostrum, entirely hidden dorsally. Antennae well separated from antennules, at least at their bases; urinary article at level of moderately developed epistome. Proepistome represented by ventral expansion of rostrum (and not rostrum itself). Lower orbital margin with one 
conspicuous knob, not visible dorsally. Mxp3 gaping at level of ischion/merus junction; merus and ischium broad, short, about subequal.

Sternum/pterygostome junction substantially developed due to extension of sternite 4. Milne-Edwards openings separated from chelipeds. Sternites 1 and 2 not separated by suture, with demarcation only visible on lateral margins; sternite 2 separated from sternite 3 by complete suture (suture 2/3); suture $3 / 4$ tiny, only lateral, at level of extension of sternite 4 . No longitudinal line. Sternopleonal cavity short, triangular. Pleons in both sexes without fused somites, except 6 fused to telson (pleotelson).

Male pleon widely triangular, regularly widening; pleotelson widely triangular, somewhat trilobed; intercalated plates salient, partially delineated, distinctly visible laterally. Male gonopore sternal. Pressbutton for pleonal-locking mechanism on lateral side of sternopleonal cavity. Female pleon oval, with five free somites plus pleotelson, discoid in ovigerous females with few, large eggs, not carried by pleopods. Vulvae located at level of sternite 6, as normally, thus not deplaced anteriorly. Gonopods stout, filling most of sternopleonal cavity. G1 curved at base, otherwise with little curvature; terminal portion bearing fine setae, terminating in one lobe, without corneous process. Paired branchiosternal canal apertures posterolaterally on sternite 8 , concealed.

Male chelipeds much stouter than walking legs; propodus inflated, covered with long soft setae partially extending on fingers; merus and carpus with stiff, regularly spaced setae; fingers not gaping. Female chelipeds narrow, propodus only slighly inflated, devoid of long setae; fingers very elongate and with finely denticulate cutting edges completely joined. Pereiopods in both sexes rather long, with margins bearing stiff, regularly spaced setae.

\section{Etymology}

The genus name is in honour of Bertrand Richer de Forges for his lifetime commitment to carcinology, especially of New Caledonia, for having always been an excellent and untiring researcher, and for his friendship.

Richerius marqueti gen. et sp. nov. urn:1sid:zoobank.org:act:CFE7F3D1-10CD-4092-96C2-25B525020D85

Figs $1-5$

\section{Etymology}

The species name is in honour of Gérard Marquet, who made extensive collections of freshwater crustaceans for more than 30 years in the Indo-Pacific islands and in particular in New Caledonia where he collected the new species here described, for his friendship and his constant enthusiasm in the field as well as in the laboratory.

\section{Type material}

Holotype (Figs 1-2, 4)

NEW CALEDONIA $\bullet \hat{0}, 4.9 \times 5.0 \mathrm{~mm}$; South Province, Bourail township, Boürou village, Pouéo River, tributary of the Néra; $21^{\circ} 26.326^{\prime} \mathrm{S}, 165^{\circ} 31.909^{\prime}$ E; 180 m a.s.1.; 28 Sep. 2016; Valentin de Mazancourt and Gérard Marquet leg.; DNA voucher: CA2188; GenBank: MT364999; MNHN-IU-2014-21500.

\section{Paratypes}

NEW CALEDONIA - South Province 1 o, $4.5 \times 4.7 \mathrm{~mm}$; same collection data as for holotype; DNA voucher: CA2189; GenBank: MT365000; MNHN-IU-2014-21504 • 1 immature; South Province, Bourail

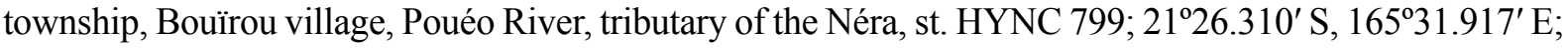
186 m a.s.1.; 17 Nov. 2017; “Our Planet Reviewed”, Hydrobio exped; Valentin de Mazancourt and Nicolas 
GUINOT D. \& MAZANCOURT V. DE, New hymenosomatid crab from New Caledonia

Charpin leg.; MNHN-IU-2014-21188 • 1 ,, $5.0 \times 5.4 \mathrm{~mm}$; same collection data as for preceding; DNA voucher: CA2185; GenBank: MT364996; MNHN-IU-2014-21505 • 1 §, $4.8 \times 5.2 \mathrm{~mm}$; same collection data as for preceding; DNA voucher: CA2186; GenBank: MT364997; MNHN-IU-2014-21506. - North Province 1 ovigerous,$+ 7.0 \times 7.1 \mathrm{~mm}$; Houaïlou township, Creek stream, tributary of the Böua at level

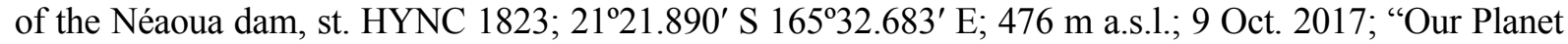
Reviewed", Hydrobio exped,; Nicolas Charpin leg.; DNA voucher: CA2197; GenBank: MT365001; MNHN-IU-2014-21501 • 1 त, $4.1 \times 4.0 \mathrm{~mm}$; same collection data as for preceding; DNA voucher: CA2198; GenBank: MT365002; MNHN-IU-2014-21502 • 3 immature specs; same collection data as for preceding; DNA voucher: CA2187; GenBak: MT364998; MNHN-IU-2014-21503.

\section{Comparative material}

Odiomaris pilosus (A. Milne-Edwards, 1873) (Figs 6-7)

NEW CALEDONIA -3 specs, syntypes of Elamene (for Elamena) pilosa, dry condition; M. Balansa leg.; MNHN-IU-2000-657 = MNHN-B657 • 3 specs, syntypes of Elamene (for Elamena) pilosa, in ethanol; M. Balansa leg.; MNHN-IU-2014-11869 = MNHN-B17725 • 2 specs, syntypes of Elamene (for Elamena) pilosa, in ethanol; M. Balansa leg.; MNHN-IU-2014-11870 = MNHN-B17726 2 specs, syntypes of Elamene (for Elamena) pilosa; RMNH D32 (see Fransen et al. 1997) 2 ovigerous 9 ; North Province, Pouébo township, Pwébalariuu stream; $20^{\circ} 30.135^{\prime}$ S, $164^{\circ} 45.618^{\prime}$ E; 12 m a.s.l.; 2 Feb. 2013; Laura Taillebois leg.; MNHN-IU-2017-9407 • 1 क ; South Province, Thio township, Petit Borindi

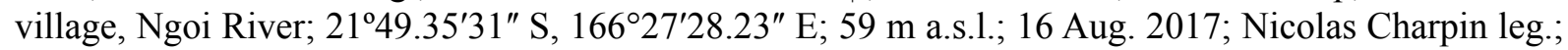
MNHN-IU-2018-2997 4 放; North Province, Kaala-Gomen township, Tegon locality, Iouanga River, st. HYNC 720; $20^{\circ} 41.032^{\prime}$ S, $164^{\circ} 23.676^{\prime}$ E; 4 m a.s.l.; 17 Nov. 2016; “Our Planet Reviewed”, Hydrobio exped.; Valentin de Mazancourt leg.; MNHN-IU-2018-2999.

\section{Odiomaris aff. pilosus}

See below 'Remarks on Odiomaris aff. pilosus from the Iouanga River and two other streams'.

Odiomaris estuarius Davie \& Richer de Forges, 1996 (Fig. 8A-B)

NEW CALEDONIA $-\hat{O}$, holotype $(4.5 \times 4.3 \mathrm{~mm})$; South Province, Dumbea estuary; 8 Dec. 1993; P. Davie and Richer de Forges leg.; MNHN-IU-2014-11855 = MNHN-B25278・4 えへ, paratypes (4.7 $\times$ $4.4 \mathrm{~mm}, 4.0 \times 3.6 \mathrm{~mm}, 3.6 \times 3.4 \mathrm{~mm}, 2.7 \times 2.7 \mathrm{~mm}), 4$ 우, paratypes $(5.4 \times 5.0 \mathrm{~mm}, 4.1 \times 3.9 \mathrm{~mm}, 4.0 \times$ $3.5 \mathrm{~mm}, 3.8 \times 3.4 \mathrm{~mm}$ ); same collection data as for holotype; MNHN-IU-2014-11856= MNHN-B25275.

Amarinus lacustris (Chilton, 1882)

AUSTRALIA • $2 \hat{\jmath} \widehat{\partial}, 3$ 우; NE Tasmania, Scamander, Scamander River; 10 Feb. 1977; M. Takeda leg.; ZRC 1993.6513.6517.

Neorhynchoplax euryrostris Davie \& Richer de Forges 1996 (Fig. 9A-B)

NEW CALEDONIA - North Province 1 spec.; Kaala-Gomen township, Tegon locality, Iouanga River, st. HYNC 720; $20^{\circ} 41.032^{\prime}$ S, $164^{\circ} 23.676^{\prime}$ E; 4 m a.s.1.; 9 Nov. 2016; "Our Planet Reviewed”, Hydrobio exped.; Valentin de Mazancourt leg.; MNHN-IU-2014-21508 • 1 spec.; same collection data as for preceding; MNHN-IU-2014-21509 1 $\delta^{\lambda}, 1$ ovigerous $\$$, 1 spec.; Canala township, stream tributary of the Negropo River, st. HYNC 790; $21^{\circ} 30.765^{\prime}$ S, $165^{\circ} 56.438^{\prime}$ E; 4 m a.s.1.; 9 Nov. 2017; "Our Planet Reviewed", Hydrobio exped.; Valentin de Mazancourt and Nicolas Charpin leg.; MNHNIU-2014-21510 • $1 \mathrm{spec}$.; same collection data as for preceding; MNHN-IU-2014-21511 • 1 spec.; same collection data as for preceding; MNHN-IU-2014-21512 $1 \mathrm{spec}$.; same collection data as for preceding; MNHN-IU-2014-21513. - South Province • 1 spec.; Bourail township, Rivière du Cap, st. HYNC 1801; $21^{\circ} 31.069^{\prime}$ S, $165^{\circ} 17.287^{\prime}$ E; 9 m a.s.1.; 4 Oct. 2017; "Our Planet Reviewed”, Hydrobio exped.; Nicolas Charpin leg.; MNHN-IU-2014-21514. 
Elamenopsis lineata A. Milne-Edwards, 1873

NEW CALEDONIA $\bullet+$, holotype $(2.6 \times 2.0 \mathrm{~mm})$; South Province, Dotio (sable du Dotio); M. Balansa leg.; MNHN-IU-2014-7783 = MNHN-B651 (see Ng \& Richer de Forges 1996: 263, fig. 1a-b; Ng \& Chuang 1996: 40, fig. 15a-b, e).

Lucascinus keijibabai (Takeda \& Miyake, 1971)

NEW CALEDONIA - South Province 1 疋; South Province, Thio; $1 \mathrm{~m}$ depth; MNHN IU-2014-7146=

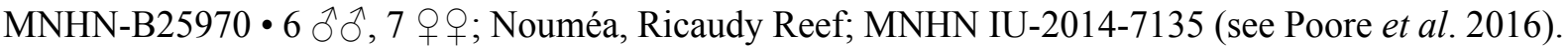

Micas minutus (A. Milne-Edwards, 1873)

NEW CALEDONIA $-\lambda$, lectotype (designated by Ng \& Richer de Forges 1996) $(3.4 \times 3.5 \mathrm{~mm}$ ); M. Marie leg.; MNHN-IU-2014-7784 = MNHN-B656 (see Ng \& Richer de Forges 1996: 265, 269, fig. 3, as MNHN-B656Sa).

Micas falcipes $\mathrm{Ng} \&$ Richer de Forges, 1996 NEW CALEDONIA $\bullet 1$ ô, paratype $(2.8 \times 2.7 \mathrm{~mm}), 1$ \% paratype $(3.1 \times 2.6 \mathrm{~mm})$; South Province, Nouméa, low tide at Ouemo; 2 Jul. 1992; B. Richer de Forges leg.; MNHN-B24915 (see Ng \& Richer de Forges 1996: 269, fig. 4, as MNHN-B24915b).

Elamena vesca $\mathrm{Ng}$ \& Richer de Forges, 1996

NEW CALEDONIA $\bullet$, holotype $(6.0 \times 5.4 \mathrm{~mm})$; South Province, Nouméa, intertidal region, low tide at Ouemo; 2 Jul. 1992; B. Richer de Forges leg.; MNHN-IU-2014-7781 = MNHN-B22843 (see Ng \& Richer de Forges 1996: fig. 8a, c-e, g-i).

\section{Description}

Carapace (Figs 1A, 5B) approximately circular to oval, slightly broader than long; dorsal carapace surface slightly concave, not strongly outlined by grooves, only with well defined gastrocardiac and thoracic grooves, approaching but not reaching antero- and posterolateral margins, respectively; no row of setae along lateral margins, except for some regularly mid-spaced setae in males; carapace angles not well marked. Anterolateral margin entire, without crenulations, lobes or teeth. Branchiostegite only weakly visible dorsally.

Eyes visible dorsally. Antennules (Fig. 1B) obliquely folded along hollowed ventral parts of rostrum and entirely hidden dorsally. Antennae well separated from antennules, at least at their bases; urinary article at level of epistome. Rostrum (Figs 1, 4, 5B-D) broadly rounded, spade-shaped, barely deflexed; dorsal surface spatulate with marked depression; carapace rim as a small ridge continuous across behind rostrum. Proepistome represented by triangular ventral expansion of rostrum (Fig. 1B). Epistome moderately developed; anterior margin undulated. Lower orbital margin with one conspicuous knob, not visible dorsally. Pterygostomial regions with setae, distinctly separated from subhepatic area by marked ridge. Mxp3 moderately gaping, broad; merus and ischium broad, short; midlength of merus slightly longer than that of ischium (Figs 1B, 2B). Sternum/pterygostome junction substantially developed due to extension of sternite 4. Milne-Edwards openings separated from chelipeds.

Male chelipeds much stouter than walking legs, particularly in large males (Fig. 4); merus and carpus with stiff, regularly spaced setae; propodus very inflated, covered with long soft setae partially extending on fingers; fingers with finely denticulate cutting edges, not gaping. Female chelipeds narrow, propodus moderately inflated, devoid of long setae; fingers proportionally rather long, with with finely denticulate cutting edges completely joined. Walking legs proportionally rather long, with margins bearing stiff, regularly spaced, scattered setae; dactyli slender but not distinctly longer than respective propodi, smoothly curved, setose, without teeth, ending in pointed tip. 


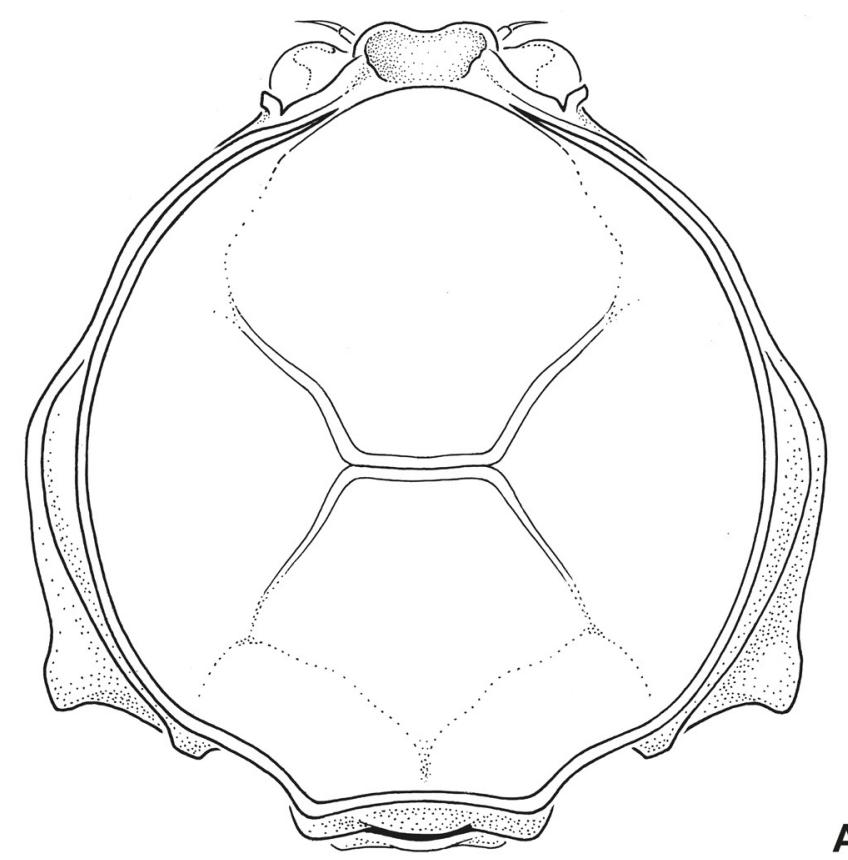

A

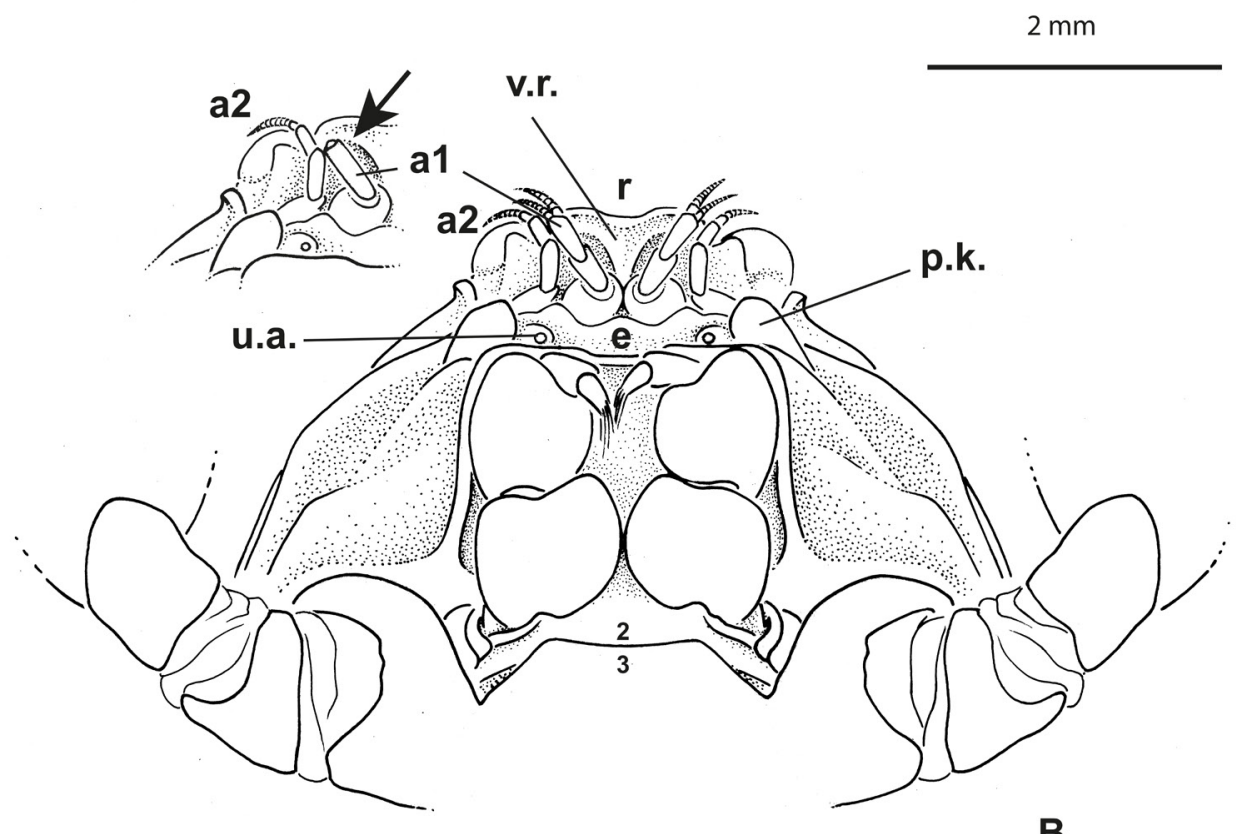

B

Fig. 1. Richerius marqueti gen. et sp. nov., holotype, ${ }^{\lambda}$, New Caledonia, South Province, $21^{\circ} 26.326^{\prime}$ S, $165^{\circ} 31.909^{\prime}$ E, Pouéo River, tributary of the Néra, Bouïrou village, Bourail township, $180 \mathrm{~m}$ a.s.l., Valentin de Mazancourt and Gérard Marquet leg., 28 Sep. 2016, $4.9 \times 5.0$ mm (MNHN-IU-2014-21500). A. Carapace, dorsal view. B. Cephalothorax, ventral view, anterior part, with unfolded antennules, the arrow shows antennule with folded second article. Abbreviations: a1 = antennule; $\mathrm{a} 2$ = antenna; $\mathrm{e}=$ epistome; p.k. $=$ postorbital $\mathrm{knob} ; \mathrm{r}=$ rostrum; u.a. $=$ antennal urinary article; v.r. $=$ ventral expansion of rostrum; $2 / 3=$ thoracic sternal suture $2 / 3$. Scale bar $=2 \mathrm{~mm}$. 

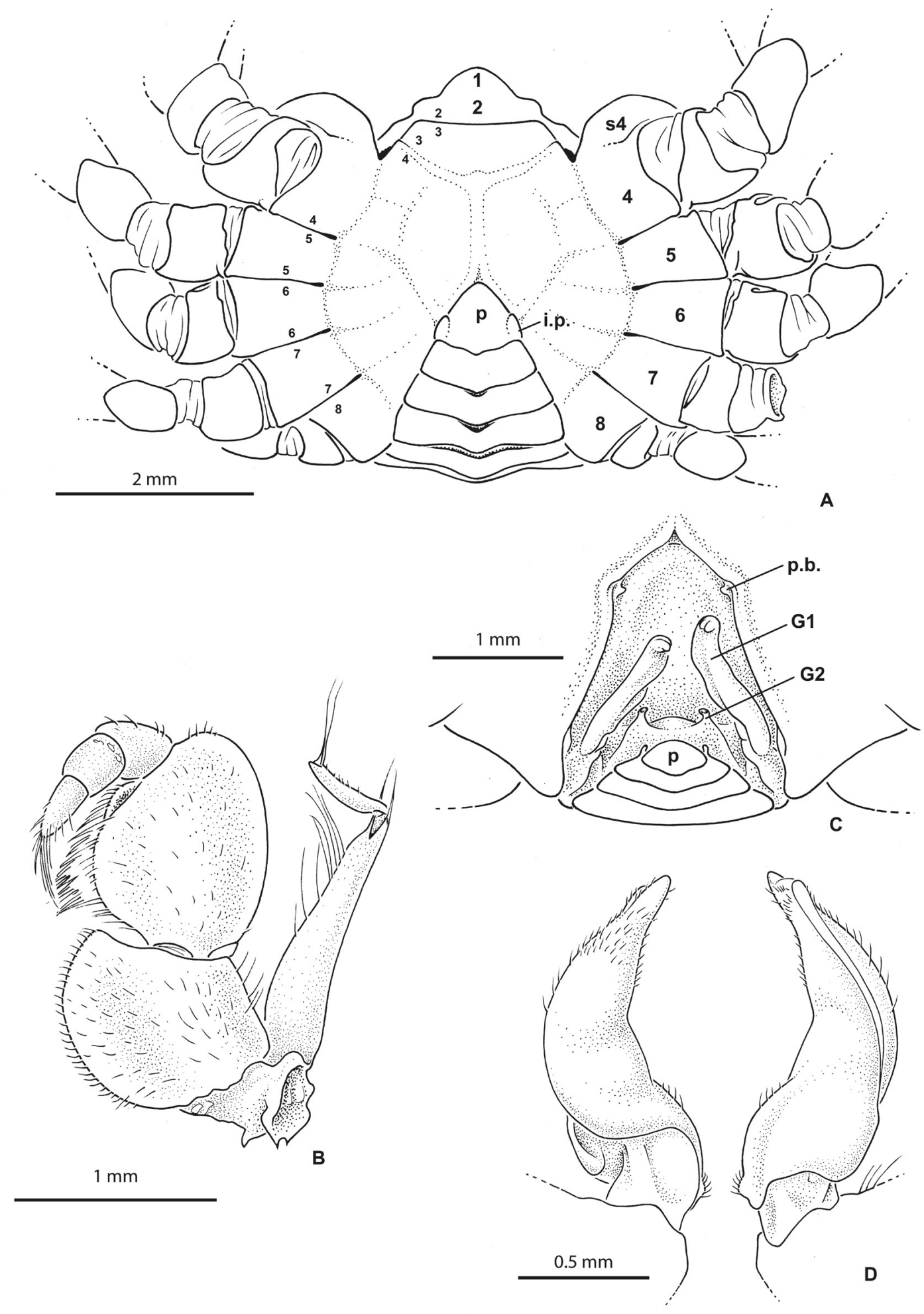

Fig. 2. Richerius marqueti gen. et sp. nov., holotype, ô, $4.9 \times 5.0 \mathrm{~mm}$ (MNHN-IU-2014-21500), same collection data as Fig. 1. A. Thoracic sternum. B. Mxp3. C. Sternopleonal cavity with G1s. D. G1, two views. Abbreviations: $\mathrm{G} 1=\operatorname{gonopod} 1 ; \mathrm{G} 2=\operatorname{gonopod} 2 ; \mathrm{i}=$ intercalated platelets; $\mathrm{p}=$ pleotelson; $\mathrm{p} . \mathrm{b} .=$ press-button; $\mathrm{s} 4=$ expansion of sternite $4 ; 1-8=$ thoracic sternites $1-8 ; 2 / 3-7 / 8=$ thoracic sternal sutures 2/3-7/8. Scale bars: A $=2 \mathrm{~mm}$; $\mathrm{B}-\mathrm{C}=1 \mathrm{~mm} ; \mathrm{D}=0.5 \mathrm{~mm}$. 

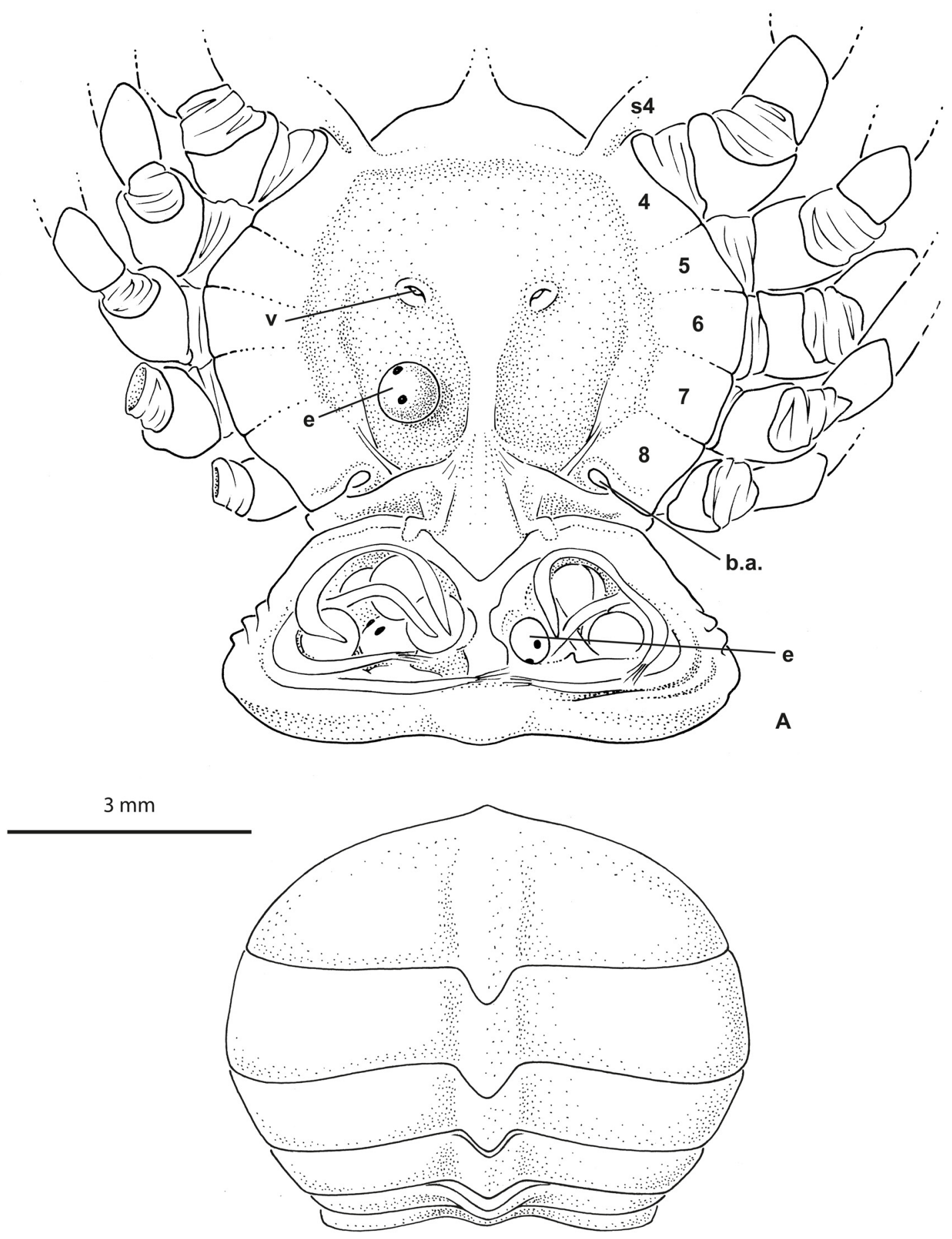

B

Fig. 3. Richerius marqueti gen. et sp. nov., paratype, ovigerous + , New Caledonia: North Province, $21^{\circ} 21.890^{\prime} \mathrm{S}, 165^{\circ} 32.683^{\prime} \mathrm{E}$, Creek stream, tributary of the Böua at level of the Néaoua dam, Houailou township, st. HYNC 1823, 476 m a.s.l., "Our Planet Reviewed", Hydrobio Expedition, Nicolas Charpin leg., 9 Oct. 2017, $7.0 \times 7.1 \mathrm{~mm}$ (MNHN-IU-2014-21501). A.Thoracic sternum, with lowered pleon. B. Pleon. Abbreviations: b.a. = branchiosternal aperture; e = egg; $\mathrm{s} 4=$ expansion of sternite 4; $\mathrm{v}=$ vulva; 4-8 $=$ thoracic sternites $4-8$. Scale bar $=3 \mathrm{~mm}$. 

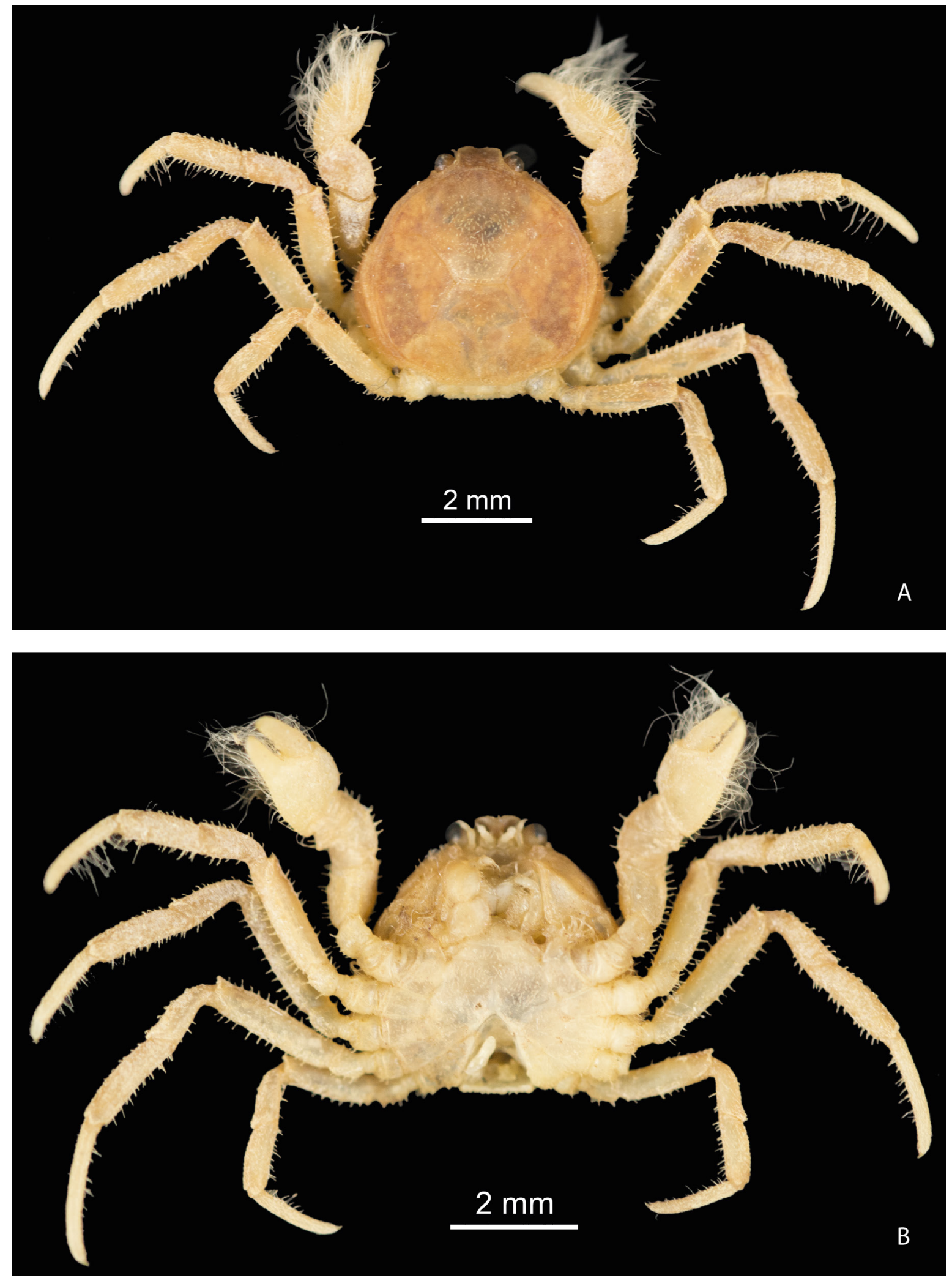

Fig. 4. Richerius marqueti gen. et sp. nov., holotype, đ̊, New Caledonia, South Province, $21^{\circ} 26.326^{\prime}$ S, $165^{\circ} 31.909^{\prime}$ E, Pouéo River, tributary of the Néra, Bouïrou village, Bourail township, $180 \mathrm{~m}$ a.s.1., Valentin de Mazancourt and Gérard Marquet leg., 28 Sep. 2016, 4.9 × 5.0 mm (MNHN-IU-2014-21500). A. Dorsal view. B. Ventral view. Scale bars $=2 \mathrm{~mm}$. 
Thoracic sternum of male (Fig. 2A) with sternites $4-8$ considerably enlarged, with suture $4 / 5$ to $7 / 8$ laterally confined. Sternites 1 and 2 not separated by suture but their demarcation visible on lateral margins; sternite 2 separated from sternite 3 by complete suture; sternite 3 as narrow pentagonal band; suture 3/4 tiny, only lateral, just at level of extension of sternite 4 . No longitudinal line. Paired branchiosternal canal apertures located posterolaterally on sternite 8 , concealed by pleon (Fig. 3A).

Sternopleonal cavity of male short, triangular, deep (Fig. 2C). Pleons in both sexes (Figs 2A, 3B) without fused somites, except 6 fused to telson, thus five somites plus pleotelson. Male pleon widely triangular, regularly widening from base to pleotelson; pleotelson widely triangular, somewhat trilobed, with intercalated plates partially delineated, salient and visible laterally at base, partially included. Pressbutton on lateral side of sternopleonal cavity (Fig. 2C). Male gonopore sternal.

Female pleon (Fig. 3A-B) oval to expanded in ovigerous females. Female pleopods $2-5$ biramous. Ovigerous females with very few and large eggs measuring $0.96 \mathrm{~mm}$ in diameter (Fig. 3A). Vulvae located on undivided portion of thoracic sternum corresponding to sternite 6 , thus not deplaced anteriorly.
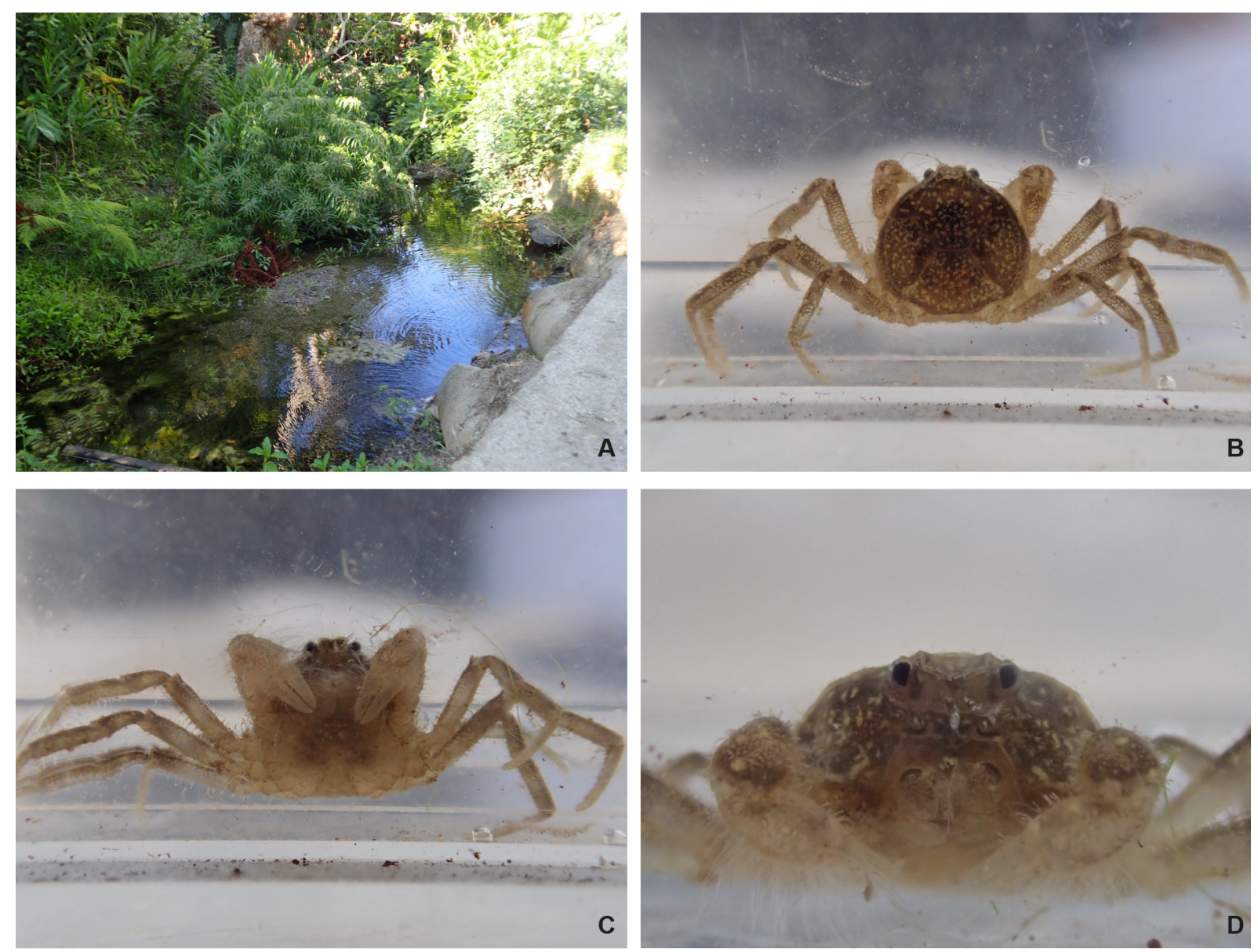

Fig. 5. Richerius marqueti gen. et sp. nov., holotype, ${ }^{\lambda}$, New Caledonia, South Province, $21^{\circ} 26.326^{\prime} \mathrm{S}$, $165^{\circ} 31.909^{\prime}$ E, Pouéo River, tributary of the Néra, Bouïrou village, Bourail township, $180 \mathrm{~m}$ a.s.l., Valentin de Mazancourt and Gérard Marquet leg., 28 Sep. 2016, $4.9 \times 5.0$ mm (MNHN-IU-2014-21500). A. Type locality, stream where several specimens of the species were collected. B-D. Views of the holotype in vivo: dorsal (B), ventral (C) and frontal (D). 
First gonopods stout, practically filling most of sternopleonal cavity (Fig. 2C). G1 curved at base, otherwise with little curvature, with terminal portion bearing fine setae, terminating in one lobe, without corneous process (Fig. 2D).

\section{Colour}

In life (Fig. 5B-D), the colour is overall brown, mottled with yellowish dots.

\section{Distribution}

Richerius marqueti gen. et sp. nov. is exclusively known from freshwaters in small flowing streams where it lives among the aquatic vegetation (Fig. 5A). It is found at an altitude of up $500 \mathrm{~m}$, therefore further from the sea than Odiomaris pilosus (that is usually encountered in the lower course of rivers). By comparison, Amarinus lacustris (Chilton, 1882) has been reported from New Zealand freshwaters from Lord Howe Island at altitudes between 61-92 m (Etheridge 1889) and even about 800-900 m (Chilton 1915; Holthuis 1968); A. angelicus Holthuis, 1968, from the central mountain range of Papua New Guinea, was collected in pure freshwater of a watercress swamp at an altitude of $1600 \mathrm{~m}$ (Holthuis 1968, 1982).

\section{Remarks}

The subfamily Odiomarinae was erected by Guinot (2011a) to receive two genera of the family Hymenosomatidae characterised by the presence on the male pleon of intercalated platelets, either articulated and moveable (Guinot 2011a: fig. 2) or relatively less well-demarcated: Odiomaris $\mathrm{Ng} \&$ Richer de Forges, 1996, endemic to New Caledonia, and Amarinu (at least pro parte), mostly from fresh and estuarine waters of the Indo-West Pacific region. Richerius gen. nov. shows several plesiomorphic characters that include the male and female pleons without fused somites (except for pleotelson), thus consisting of six elements (namely the maximum of somites existing in Hymenosomatidae), the prominent, partially demarcated intercalated platelets, the thoracic sternum with the anterior sternites forming a small produced plate, the vulvae not anteriorly displaced, the G1 only gently curved and simple. Richerius gen. nov. can be assigned to the Odiomarinae.

Odiomaris is known from two species: the type species Elamena pilosa A. Milne-Edwards, 1873, referred to as Halicarcinus White, 1846 by Holthuis (1968), as Amarinus by Lucas (1980) then as Odiomaris by Ng \& Richer de Forges (1996), mainly freshwater but also euryhaline; and O. estuarius Davie \& Richer de Forges, 1996, exclusively brackish. An important difference between these two species is the rostrum: it is lowered ventrally as a triangular, V-shaped projection in O. pilosus so as to be positioned between the antennules (Fig. 7A) (A. Milne-Edwards 1873: pl. 18, fig. 6a, as Elamene pilosa; Ng \& Richer de Forges 1996: fig. 6c-d), whereas it is spatulate and does not extend to form a ventral projection between the antennules in O. estuarius (Fig. 8A-B) (Davie \& Richer de Forges 1996: fig. 1a-b).

Richerius gen. nov. shares with Odiomaris the same arrangement of the cephalic appendices. But its rostrum is spatulate without folding down ventrally (Figs 1, 4, 5D), instead of being lowered ventrally as a V-shaped projection located between the antennules as in Odiomaris pilosus (Fig. 7A). In Richerius gen. nov. (Fig. 1B), the proepistome is represented by a ventral expansion of the rostrum; therefore, the antennules are located along the proepistome, whereas in Odiomaris pilosus the antennules are obliquely folded in a fossa hollowed all along with the lateral parts of the V-shaped rostrum and the eye. Richerius marqueti gen. et sp. nov. actually has a rostrum and proepistome more similar to those of O. estuarius (Fig. 8) (Davie \& Richer de Forges 1996: fig. 1) than to those of O. pilosus. In fact, the genus-level differences between Richerius gen. nov. and Odiomaris remain unclear. Actually, O. estuarius seems morphologically closer to Richerius gen. nov. than to O. pilosus, at least in some 
characteristics. A possible transfer of $O$. estuarius to Richerius gen. nov. has been considered but needs to be decided later, especially when the status of Odiomaris aff. pilosus is resolved (see below, 'Remarks on Odiomaris aff. pilosus from the Iouanga River and two other streams').

Along the lower orbital margin there are two salient knobs in both species of Odiomaris, both prominent in dorsal view in O. pilosus (A. Milne-Edwards 1873: pl. 18, fig. 6a; Ng \& Richer de Forges 1996: fig. 6a, d, not figured in fig. 6c; Guinot \& Richer de Forges 1997: figs 1a, c, 2c), but shorter and not dorsally visible in O. estuarius (Davie \& Richer de Forges 1996: fig. 1a; not figured in fig. 1b). In contrast, there is only one, smaller knob in Richerius gen. nov. (Fig. 1B). The cheliped palm of R. marqueti gen. et sp. nov. is covered with long, flexible setae (Fig. 5C-D), instead of numerous spinules (or stiff setae) in O. pilosus (Fig. 6) (A. Milne-Edwards, 1873: pl. 18, fig. 6d; Ng \& Richer de Forges 1996: fig. 6f), and sparse, short setae in O. estuarius (Fig. 8). In fact, the whole body (including the margins of the rostrum) and legs of $O$. pilosus are covered with spiniform, stiff setae that give a bristle appearance ( $\mathrm{Ng} \&$ Richer de Forges 1996: figs 5a-b, 6a, d; Guinot \& Richer de Forges 1997: fig. 1a), whereas O. estuarius has a carapace with soft, short setae and legs with longer setae (Davie \& Richer de Forges 1996: fig. 1a). The male cheliped fingers are practically joining in $R$. marqueti gen. et sp. nov. (Fig. 5C), but with a broad proximal gap in $O$. pilosus (Fig. 6A-B) (A. Milne-Edwards 1873: 322, pl. 18, fig. 6, 6d, as Elamene pilosa; Ng \& Richer de Forges 1996: fig. 6f); in O. estuarius the chelae are narrower, with long fingers without marked gap (Fig. 8A-B) (Davie \& Richer de Forges 1996: fig. 1). The grooves on the carapace dorsal surface are very distinct in $O$. pilosus, well marked in $R$. marqueti gen. et sp. nov., whereas almost indiscernible in O. estuarius. The sterno-pleonal cavity is short in Richerius gen. nov. and in Odiomaris, and accordingly the pleon also. The male pleon is as a narrow triangle, with a long pleotelson in both Odiomaris species (A. Milne-Edwards 1873: pl. 18, fig. 6b, as Elamene pilosa; Ng \& Richer de Forges 1996: fig. 7a-b; Guinot \& Richer de Forges 1997: fig. 2a: O. pilosus; Davie \& Richer de Forges 1996: fig. 2c: O. estuarius), markedly wider and with a much shorter pleotelson in $R$. marqueti gen. et sp. nov. (Fig. 2A). The intercalated platelets, which are completely demarcated and moveable in $O$. pilosus (Guinot 2011a: fig. 2), are only partially delineated in $R$. marqueti gen. et sp. nov., and not detached in O. estuarius. The female pleon is rather similar in Richerius gen. nov. and Odiomaris, with five somites plus pleotelson. The G1 of Richerius gen. nov. (Fig. 2D) is curved at the base, otherwise with little curvature, with a terminal portion bearing fine setae and ending in one lobe without corneous process, whereas the G1 of Odiomaris is characterised by two distinct distal processes, a longer corneous process and a shorter lobular elongation of the stem (Fig. 7B: O. pilosus) (Ng \& Richer de Forges 1996: fig. 7cd: O. pilosus; Davie \& Richer de Forges 1996: fig. 2c: O. estuarius). O. estuarius is a much smaller species than $O$. pilosus, and $R$. marqueti gen. et sp. nov. seems to be nearly as small as $O$. estuarius.

The main differences to distinguish the two genera Odiomaris and Amarinus stated by Davie \& Richer de Forges (1996: 259) were: 1) in Odiomaris, the G1 (see Fig. 7B) more slender, with two distinct distal processes, a longer corneous process and a shorter lobular elongation of the stem than in Amarinus; 2) in Odiomaris, the elongated triangular telson of the male pleon is significantly longer than wide at base, whereas in Amarinus the telson is more or less rounded and short, being much wider than long.

The genus Amarinus Lucas, 1980 (type species by original designation: Elamena lacustris Chilton, 1882) is known from more than ten species. They all inhabit low salinity environments, from brackish habitats to pure freshwater waters permanently (streams, lakes, swamps), and have a large distribution (New Zealand, Australia, Indonesia, the Philippines, Papua New Guinea). Cases where Amarinus has been reported from New Caledonia, as in Chuang \& $\mathrm{Ng}$ (1994: 87, 90, table 1, under A. pilosus) and erroneously as in Guinot (2011a: 23), are attributable to the fact that the species pilosus was previously associated with the genus Amarinus (see Lucas 1980) until Ng \& Richer de Forges (1996) made it the type species of their new genus Odiomaris. So far, no species of Amarinus has actually been reported in New Caledonia. Suspecting that our new species might belong to the genus Amarinus, we therefore 
carefully compared Richerius gen. nov. to Amarinus, and in particular to its type species, A. lacustris, another freshwater hymenosomatid.

Richerius marqueti gen. et sp. nov. can be distinguished from Amarinus lacustris by: the wide male pleon, with prominent marks corresponding to intercalated platelets (Fig. 2A) (versus narrow and without intercalated platelets in A. lacustris, see Melrose 1975: fig. 42g; Lucas 1980: fig. 7b); the G1 rather narrow and with one distal lobe without corneous process (Fig. 2D) (versus stout and without lobes, see Melrose 1975: fig. 42h-i; Lucas 1980: fig. 10e); and by the arrangement of antennules and antennae.

In providing a key of the Southeast Asian hymenosomatids, Ng \& Chuang (1996: 3-5, 6-12) have shown the presence of several groups of species within Amarinus, suggesting that the genus could be paraphyletic. Today, another problem arises, especially regarding the antennular morphology. Melrose (1975: 84, 87, figs 41-42, as Halicarcinus lacustris), who has thoroughly studied the type species A. lacustris, confined to lakes and non-tidal rivers of New Zealand and southeastern Australia, states that the antennules are "small, not visible dorsally when folded". Her figure $41 \mathrm{~d}$ actually seems to show a folded antennule, only with the broad basal article and the second cylindrical article, without the short, supposedly folded flagellum being seen [the frontal view of fig. 41e in Melrose (1975) shows a complete, unfolded antennule]. Our examination of Amarinus lacustris, on the other hand, reveals that both antennules and antennae are inserted very closely together at their bases and remain parallel, with both flagella visible dorsally, as represented by Lucas (1980: fig. 1d) for a generalised hymenosomatid or by Melrose (1975: fig. 43c) for Halicarinus tongi Melrose, 1975. In fact, if it is possible for the antennule of A. lacustris to fold itself down [but not obliquely along the rostrum as in Odiomaris (Fig. 7A), see A. Milne-Edwards 1873: pl. 18, fig. 6a], this does not correspond to the resting position. In the seven specimens of $A$. lacustris examined, the antennule and antenna are very closely inserted and remain parallel, both being stretched forward; the unfolded flagellum is visible dorsally in all individuals. In any event, the disposition of the antennule and antenna differs from that Odiomaris (Fig. 7A: O. pilosus) (Ng \& Richer de Forges 1996: fig. 6c-d: O. pilosus).

A picture of the cephalic region in ventral view of Amarinus angelicus (Holthuis 1968: 114, fig. 2b) shows an antennule "entirely hidden below the rostrum", obliquely folded, which does not seem to correspond to the condition of $A$. lacustris. This character deserves to be reviewed for all species of Amarinus, and the allocation of Amarinus (including the type species and other included species) to the Odiomarinae needs further investigation. In the new species described here, Richerius marqueti gen. et sp. nov. (Fig. 1B), the antennule and antenna are separated at least at their insertion site, and only the antennal flagellum is visible dorsally; thus it shares an arrangement substantially similar to that of Odiomaris.

It was the study of spermatozoa carried out first in the two species of Odiomaris, O. pilosus and O. estuarius, by Richer de Forges et al. (1997) and later in Elamena vesca by Jamieson \& Tudge (2000) that showed the very particular nature of the hymenosomatid sperm within the Brachyura. Indeed, they are distinguished by at least nine major characteristics from those of all the other Brachyura taxa studied, particularly the groups with which they have been associated, the Majoidea Samouelle, 1819 and the Thoracotremata Guinot, 1977. The 'hymenosomatid-type of spermatozoon' is unique within Brachyura (Tudge et al. 2014). The highly developed projection of the acrosome from the nucleus in hymenosomatid spermatozoon recalls the totally emergent acrosome of Podotremata Guinot, 1977 and may represent the plesiomorphic condition in the Eubrachyura Saint Laurent, 1980 (Guinot 2011a, 2011b).

\section{Remarks on Odiomaris aff. pilosus from the Iouanga River and two other streams}

A lot of specimens obtained belatedly in the course of our research poses a problem: collected in the Iouanga River on 17 November 2016 (see Fig. 10) (MNHN-IU-2018-2999) and previously identified 
to Odiomaris pilosus, they split into two species: four males are certainly $O$. pilosus, but about twenty individuals of various sizes (a few males and a larger number of females) do not correspond either to this species or to Richerius marqueti gen. et sp. nov.; nor is it identifiable with Odiomaris estuarius. The same unidentified species was found in another stream of the North Province and is believed to inhabit another stream in the South Province (Fig. 10) (manuscript in progress).

\section{Material examined}

NEW CALEDONIA - North Province $-8 \hat{\delta}, 7$ ovigerous $q 9+, 13$ subadults and inmatures; Kaala-Gomen township, Tegon locality, Iouanga River, st. HYNC 720; $20^{\circ} 41.032^{\prime} \mathrm{S}, 164^{\circ} 23.676^{\prime} \mathrm{E}$; 4 m a.s.1.; 17 Nov. 2016; "Our Planet Reviewed", Hydrobio exped.; Valentin de Mazancourt leg.; MNHN-IU-2018-2999 • 1 ; ; Canala township, stream tributary of the Negropo River, st. HYNC 790; $21^{\circ} 30.765^{\prime} \mathrm{S}, 165^{\circ} 56.438^{\prime}$ E; 4 m a.s.1.; 9 Nov. 2017; “Our Planet Reviewed”, Hydrobio exped.; Valentin de Mazancourt and Nicolas Charpin leg.; MNHN-IU-2018-3001.

\section{The hymenosomatid fauna of New Caledonia}

The checklist of brachyuran crabs from New Caledonia (the area considered included the Loyalty Islands, Chesterfield and Bellona Plateau and Lord Howe seamounts, Matthew \& Hunter Islands as well as the Norfolk Ridge seamounts) established by Ng \& Richer de Forges (2007) included 558 species. New Caledonia (Fig. 10), a very old, isolated Darwinian island dating to $37 \mathrm{Ma}$ (Grandcolas et al. 2008), does not host any of the exclusively freshwater crabs that undergo direct development and belong to various primarily freshwater families (Yeo et al. 2008). But crabs found in freshwater include also numerous euryhaline species or secondary freshwater species from primarily marine brachyuran stock, such as Australocarcinus kanaka Davie \& Guinot, 1996 (Chasmocarcinidae Serène, 1964, Trogloplacinae Guinot, 1986) recorded up to $400 \mathrm{~m}$ above sea level in various New Caledonian freshwater habitats (Davie \& Guinot 1996). This is also the case of some species of the family Hymenosomatidae that, with 119 species in 19 genera (updated from Ng et al. 2008: 108; Davie et al. 2015b) distributed worldwide (also throughout the southern hemisphere, also circumpolar in the subantarctic region), is found in a wide variety of environments: from the open ocean: $244 \mathrm{~m}$ depth from Taupo Seamount, Tasman Sea, for Micas lucasi (Richer de Forges, 1993) (Richer de Forges 1993, as Halicarcinus lucasi); about $500 \mathrm{~m}$ depth for Halicarcinus tongi Melrose, 1975 (Melrose 1975); estuarine and brackish waters (Lucas \& Davie 1982); inland freshwaters (e.g., Lucas 1980; Lucas \& Davie 1982; McLay 1988; Ng \& Chuang 1996); swamps at an altitude of $1600 \mathrm{~m}$ (Holthuis 1968); pools of arid zones (Kemp 1917; Ali et al. 1995; 2000); caves (Ng 1991; Naruse et al. 2008b); it may be also symbiotic with echinoderms (Lucas 1980; Poore 2004). Hymenosomatids are probably the most ecologically diverse group of crabs, indicative of successful morphological adaptations (Guinot 2011a). Freshwater taxa are present everywhere (including the Philippines, India, Sulawesi, New Guinea, New Caledonia, Australia and New Zealand).

Hymenosomatids have no more than three stages zoeae in marine species and display unique characters, including the absence of a megalopa stage in the larval development of all its members, as well as occurrence in marine, brackish and freshwater habitats (Rice 1980, 1981a, 1981b, 1983; Fukuda 1981; Rabalais \& Gore 1985; Krishnan \& Kannupandi 1988; Dornelas et al. 2003; Guinot 2011a, 2011b). Some estuarine species and all freshwater species have a direct development (Lucas 1971; Chuang \& Ng 1994; Wear \& Fielder 1985): for example, Amarinus lacustris is known to carry ca 35 eggs (Lucas 1980: 202, table 4); the cave-dwelling Sulaplax ensifer Naruse, Ng \& Guinot, 2008 possesses the largest eggs (mean $1.19 \mathrm{~mm}, \mathrm{n}=10$ ) and the smallest clutch size (17 eggs) known for any hymenosomatid crab (Naruse et al. 2008b). The troglobitic Cancrocaeca xenomorpha $\mathrm{Ng}, 1991$, from Sulawesi and confined to freshwater and most common on pieces of driftwood brought into the caves by rivers, can only have a direct development (Ng 1991; Chuang \& Ng 1994; Naruse et al. 2008a). A female of Neorhynchoplax bovis (Barnard, 1946), an estuarine species, contained 13 juveniles under the pleon (Barnard 1950: 72, as 

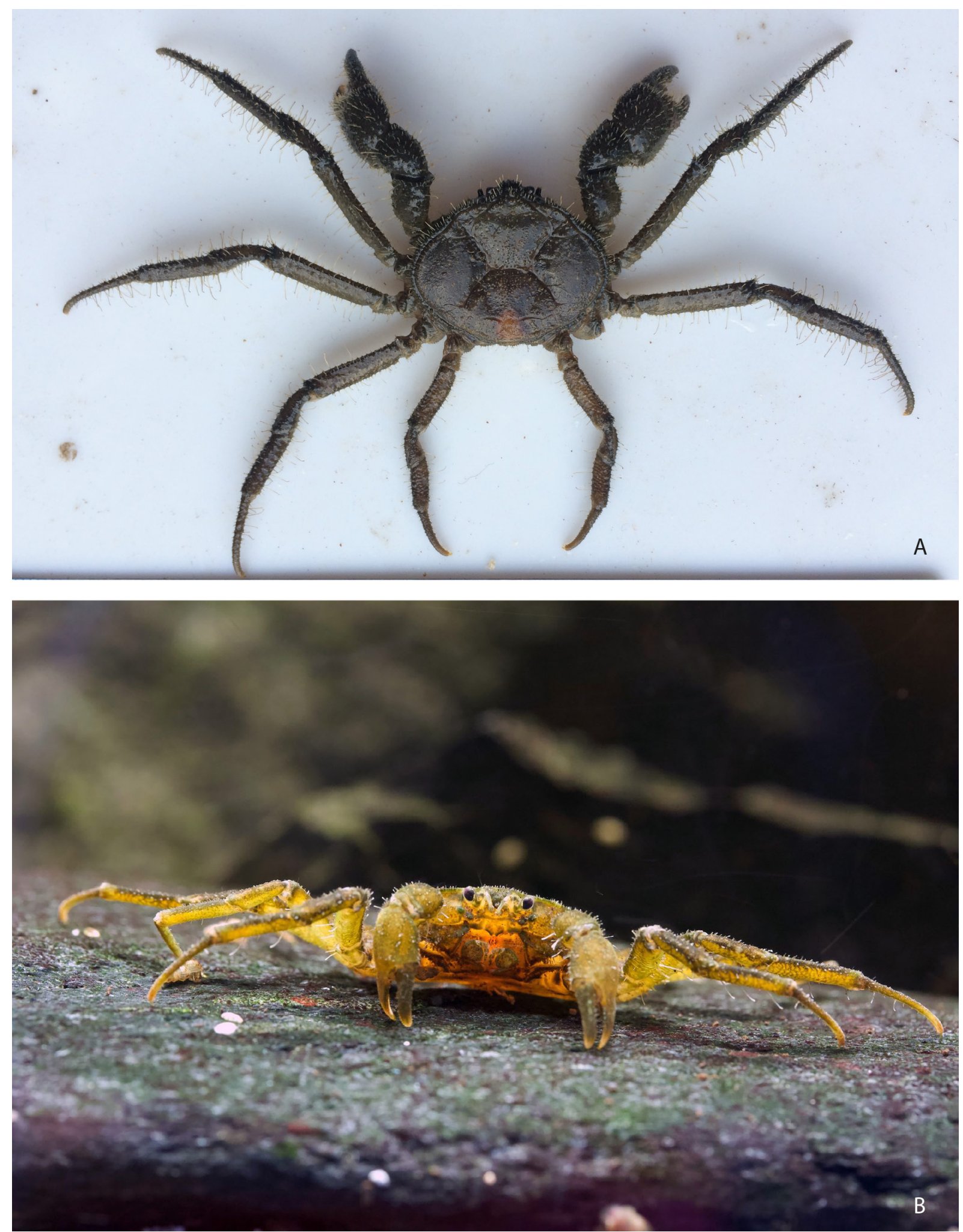

Fig. 6. Odiomaris pilosus A. Milne-Edwards, 1873, living specimens. A. Collected from the river Hiit (North Province, Hienghène township). B. Collected from the Baie Nord creek (South Province, MontDore township). Credit: Nicolas Charpin - Photographies Vies d'Ô douce. 
Rhynchoplax bovis). In lower Mesopotamia, Iraq, Elamenopsis kempi is adapted to live among branches of a water plant in a habitat of oligohaline brackish water with a salinity of 1.3-2.7\%o and a temperature range of $12-35^{\circ} \mathrm{C}$ (Chuang \& Ng 1994; Ali et al. 1995, 2000). Considering the habits and habitat of the New Caledonian freshwater species Odiomaris pilosus and Richerius marqueti gen. et sp. nov., which live even further from the sea and are found above sea level and even at relatively high altitude, it is likely that both have direct development. A few large eggs of about $1.0 \mathrm{~mm}$ in diameter and forming a small clutch are present under the female pleon of $R$. marqueti gen. et sp. nov. (Fig. 3A).

The present revision of the taxonomy of all the species of Hymenosomatidae known so far from New Caledonia provides interesting results. Until 1996, all species in New Caledonia had been known for more than 140 years, each described by A. Milne-Edwards (1873). And, with the exception of Elamenopsis lineata A. Milne-Edwards, 1873 that has remained unchanged over these years, all were assigned to new genera by Davie \& Richer de Forges (1996), Ng \& Richer de Forges (1996), Poore et al. (2016) and Komai \& Poore (2016).

The hymenosomatid fauna of New Caledonia comprises secondary freshwater, brackish and marine species. To date, only one species, Odiomaris pilosus, has been known from shallow fresh waters of the Island, from the estuary inland for several kilometres, in rivers with rapid currents. Richerius marqueti gen. et sp. nov. is a more inland species found in two streams at $180 \mathrm{~m}$ and $500 \mathrm{~m}$ of altitude. A third species, here tentatively named Odiomaris aff. pilosus, also inhabits streams but close to the sea and is euryhaline (manuscript in progress).

It should be noted our revision is preliminary, as recent expeditions (KOUMAC 2018, 2019), aimed at updating the marine biodiversity inventory of New Caledonia, show the existence of more taxa to be studied.

The currently known genera and species are as follows.

Genus Odiomaris Ng \& Richer de Forges, 1996

Type species by original designation: Elamena pilosa A. Milne-Edwards, 1873. With two species: O. pilosus (A. Milne-Edwards, 1873) and O. estuarius Davie \& Richer de Forges, 1996, both described from New Caledonia and endemic.
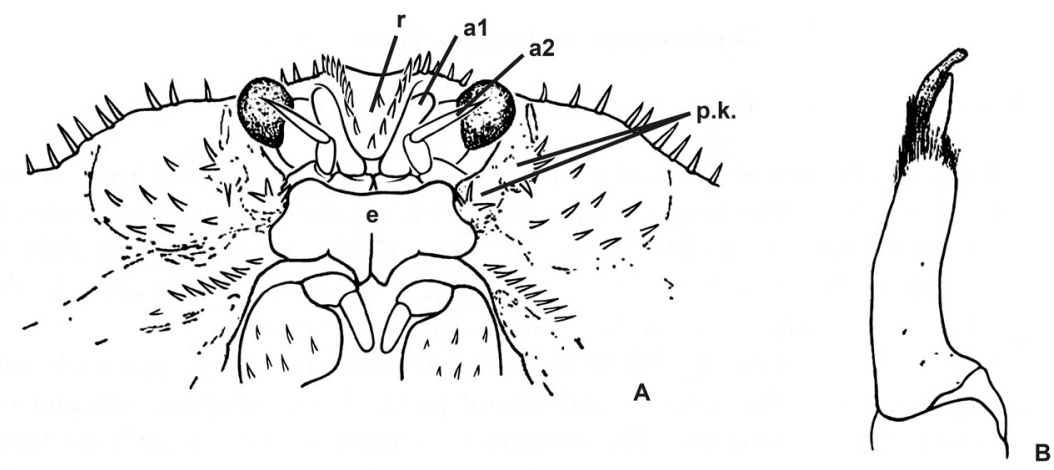

Fig. 7. Odiomaris pilosus A. Milne-Edwards, 1873, syntype, Ō, New Caledonia, freshwater, B. Balansa leg. (RMNH D 32). A. Ventral anterior part. B. G1 (after Holthuis 1968: fig. 3a-b). Abbreviations: a1 = antennule, with folded second article; $\mathrm{a} 2=$ antenna; $\mathrm{e}=$ epistome: $\mathrm{p} . \mathrm{k} .=$ postorbital knobs; $\mathrm{r}=$ rostrum. 
Odiomaris pilosus (A. Milne-Edwards, 1873)

Figs 6-7

Characterised by numerous thin, stiff spinules on carapace margins, rostrum, pterygostomial regions, walking legs and chelipeds, is the largest freshwater hymenosomatid crab known ( $\mathrm{Ng} \&$ Richer de Forges 1996: 6, figs 5-7; 2007: 317; Guinot \& Richer de Forges 1997: 460, figs 1a-d, 2a-f; Richer de Forges et al. 1997: 234; Juncker \& Poupin 2009: 11, pl. 5: two photos; Poupin 2010: 59; Davie et al. 2015a: fig. 71-2.1.e; 2015b: 947). According to Richer de Forges et al. (1997: 234), the species is common in New Caledonian rivers from the estuary inland for several kilometres, in shallow freshwaters, under or between rocks in rivers with rapid currents (G. Marquet, pers. com.); in some drainages, it is a dominant species (Marquet et al. 2003: 108, fig. p. 109).

Odiomaris estuarius Davie \& Richer de Forges, 1996

Fig. 8

Odiomaris estuarius Davie \& Richer de Forges, 1996: 257, figs 1, 2a, c

A much smaller species, until now only known from the type locality on the west coast of New Caledonia, Dumbea estuary, under logs, has more marine tendencies than O. pilosus (Marquet et al. 2003: 108).

\section{Odiomaris aff. pilosus}

See above, 'Remarks on Odiomaris aff. pilosus from the Iouanga River and two other streams'.

Genus Neorhynchoplax Sakai, 1938

Type species by subsequent designation by Holthuis (1968): Rhynchoplax introversus Kemp, 1917. The genus Neorhynchoplax, the richest hymenosomatid genus, currently contains more than 30 species, all from the Indo-West Pacific (Ng et al. 2008, 2011: 53; Hsueh 2018: table 1), with nine species described from Indian waters (Alcock 1900; Kemp 1917; Chopra \& Das 1930; Ng et al. 2011: table 2; Rahayu et al. 2020).

Several species of Neorhynchoplax are regarded as true freshwater species: $N$. dentata Ng, 1995 (Sarawak, Malaysia), N. inermis Takeda \& Miyake, 1971 (Palau Islands), N. introversa (Kemp, 1917) (Kiangsu, China), N. kempi (Chopra \& Das, 1930) (Basra, Iraq), N. prima Ng \& Chuang, 1996 (Pulau Bintan, Indonesia), N. frontalis (Lucas \& Davie, 1982) (NE Queensland, Australia), N. hirtirostris (Lucas \& Davie, 1982) (NE Queensland, Australia), N. nasalis (Kemp, 1917) (Kiangsu, China), N. pageti Pretzmann, 1975 (Madampe, Sri Lanka), N. patnahi Ng, Nesemann \& Sharma, 2011 (Patna, Bihar, India), N. thorsborneorum (Lucas \& Davie, 1982) (NE Queensland, Australia), N. yaeyamaensis Naruse, Shokita \& Kawahara, 2005 (Yaeyama Islands, Japan) (see Shen 1932; Chuang \& Ng 1994; Ng et al. 1999, 2008, 2011; Naruse et al. 2008b; Hsueh 2018). Others species are from brackish waters or are marine intertidal and marine subtidal.

Neorhynchoplax euryrostris Davie \& Richer de Forges, 1996

Fig. 9

Neorhynchoplax euryrostris Davie \& Richer de Forges, 1996: 260, figs 2b, d, 3. 
Belongs to the group of species of Neorhynchoplax in which the lateral carapace margin is armed with a distinct recurved spiniform tooth just above the first ambulatory leg (P2); a characteristic shared with Richerius marqueti gen. et sp. nov. is the long setae that cover the outer surface of the stout palm and the fingers of the chelipeds, especially in males (Fig. 9). It is estuarine to tidal freshwater. The species was
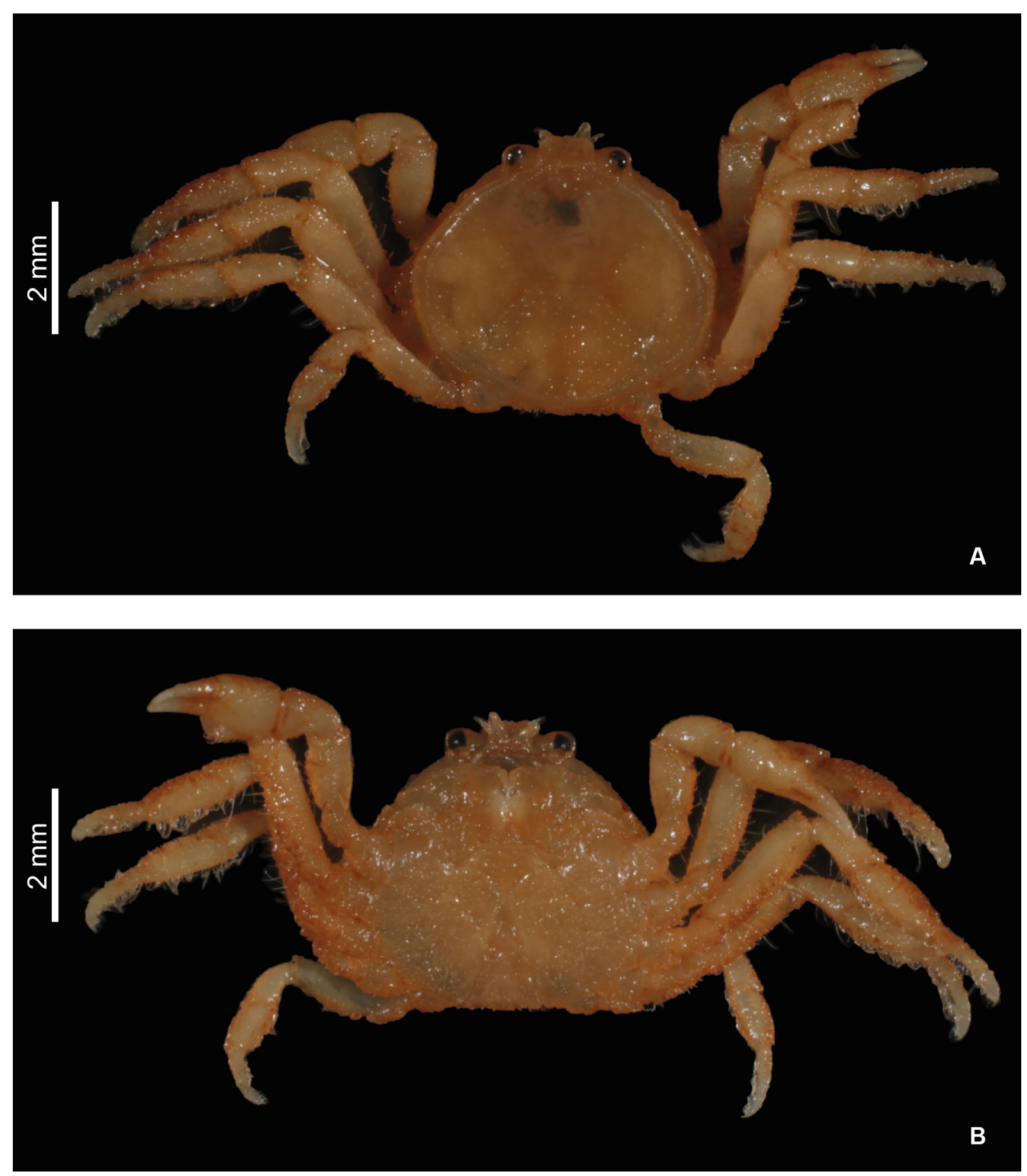

Fig. 8. Odiomaris estuarius Davie \& Richer de Forges, 1996, holotype, Ô, New Caledonia, Dumbea estuary, Davie \& Richer de Forges leg., 8 Dec. 1993, $4.5 \times 4.3 \mathrm{~mm}$ (MNHN-IU-2014-11870= MNHN-B25278). A. Dorsal view. B. Ventral view. Credit: RECOLNAT (ANR-11-INBS-0004) - Noémy MOLLARET - 2017. 

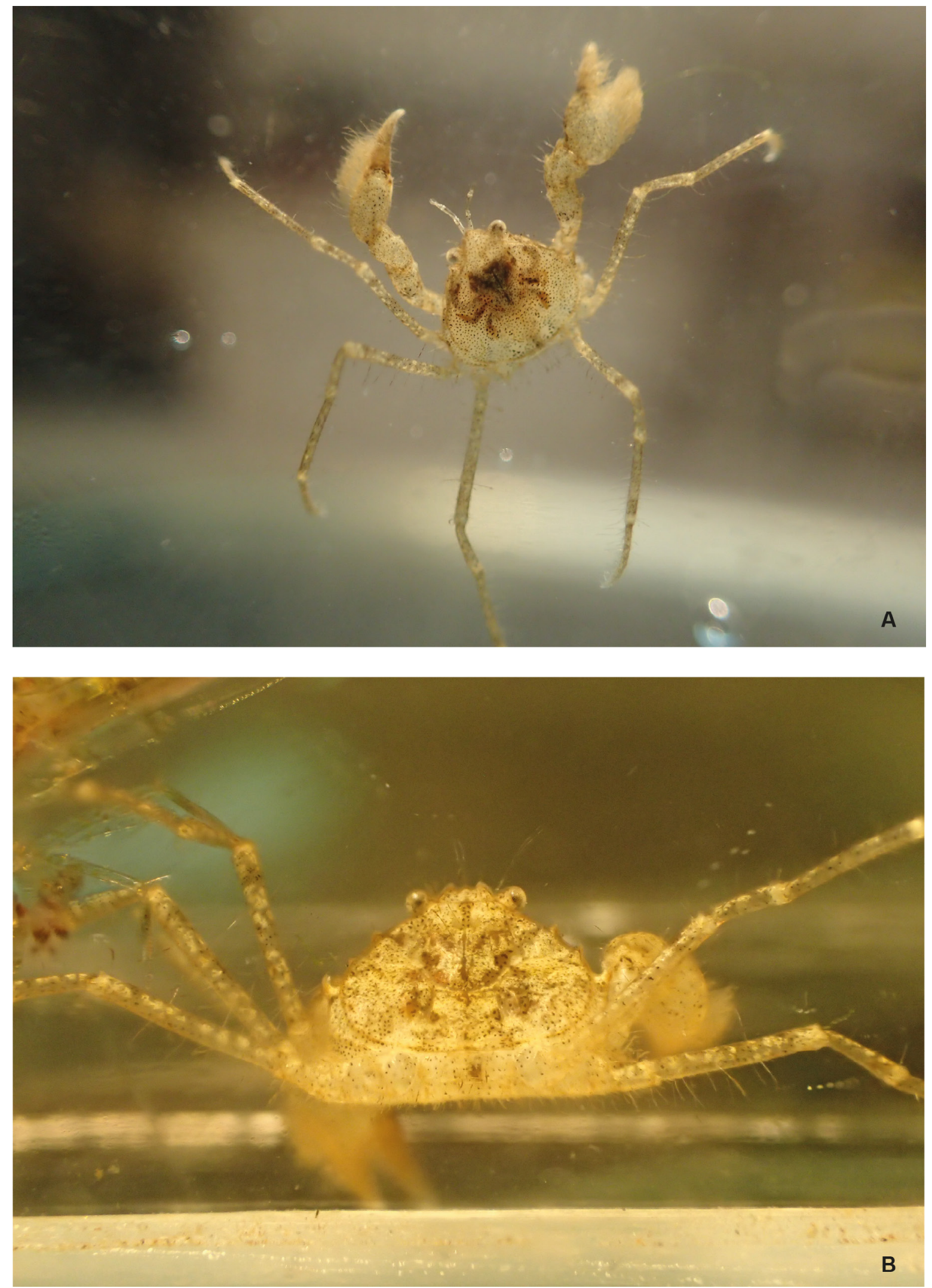

Fig. 9. Neorhynchoplax euryrostris Davie \& Richer de Forges 1996, living specimen collected in the Iouanga River, North Province, Kaala-Gomen township (MNHN-IU-2014-21508). A-B. Two views. 
until now only known from the type material collected on the western coast of New Caledonia (Dumbea, Le Cap) where it inhabits crevices in rotting logs at the edge of the water at low tide; and under stones in freshwater (Davie \& Richer de Forges 1996: 261). Thanks to the Hydrobio Expedition, "Our Planet Reviewed", it was found in the Iouanga River and in a stream tributary of the Negropo river, at $4 \mathrm{~m}$ a.s.l., where it cohabits with Odiomaris aff. pilosus. These newly collected specimens were all found in a similar habitat, among aquatic vegetation in the lower part of the river under the marine influence, with a variable salinity ranging from freshwater to brackish water depending on the tide.

Genus Elamenopsis A. Milne-Edwards, 1873

Type species by monotypy: Elamenopsis lineata A. Milne-Edwards, 1873.

Elamenopsis lineata A. Milne-Edwards, 1873

Elamenopsis lineatus [sic] A. Milne-Edwards, 1873: 324, pl. 18, fig. 4

Elamenopsis lineatus - Kemp 1917: 250. — Tesch 1918: 26, pl. 1, fig. 5, 5a-c. — Serène \& Umali 1970: 58, pl. 5, fig. 11. — Chuang \& Ng 1994: 86, table 1.

Elamenopsis lineata - Lucas 1980: 192, figs 3j, 5j, 8e, 10j. — Ng \& Richer de Forges 1996: 263, fig. 1. — Ng \& Chuang 1996: 4 (key), 19, 40, figs 15-6. — Guinot \& Richer de Forges 1997: 468, figs 4j-1, $7 \mathrm{~b}$.

Not Elamenopsis lineata Rahayu \& Ng, 2004 (=Elamenopsis gracilipes Rahayu \& Ng, 2019; see Rahayu \& Ng 2019).

Elamenopsis lineata, based on one specimen collected at Dotio, New Caledonia (and whose holotype is not a male as reported by A. Milne-Edwards in 1873 but a female as noted by Lucas in 1980) and redescribed by Ng \& Chuang (1996: 40, figs 15-16), was not collected by the Hydrobio Expedition. The species is known from Queensland (Australia) and Sulawesi (Indonesia) (Ng \& Chuang 1996). It is an estuarine species, found in sandy mud, and in mangrove area.

Genus Lucascinus Poore, Guinot, Komai \& Naruse, 2016

Type species by original designation: Halicarcinus bedfordi Montgomery, 1931.

Lucascinus keijibabai (Takeda \& Miyake, 1971)

Rhynchoplax keijibabai Takeda \& Miyake, 1971: 165-168, figs 1-2.

Halicarcinus keijibabai - Lucas 1980: 164. — Ng \& Richer de Forges 1996: 265, fig. 2.

Lucascinus keijibabai - Poore et al. 2016: 506, fig. 10h.

This species, from "intertidal reef" according to Poore et al. (2016: 506), seems endemic to New Caledonia.

Genus Micas Ng \& Richer de Forges, 1996

Type species by original designation: Elamena minuta A. Milne-Edwards, 1873.

Micas falcipes $\mathrm{Ng} \&$ Richer de Forges, 1996

Elamene [sic] minuta A. Milne-Edwards, 1873: 324 (pro parte). 
Micas falcipes Ng \& Richer de Forges, 1996: 269-271, fig. 4.

Elamena minuta - Tesch 1918: 21 (pro parte).

Halicarcinus minutus - Lucas 1980: 177 (pro parte). — Chuang \& Ng 1994: 88 (pro parte).

Micas falcipes - Poore et al. 2016: 494.

This species is only known from New Caledonian shallow reef.

Micas minutus (A. Milne-Edwards, 1873)

Elamene [sic] minuta A. Milne-Edwards, 1873: 324 (pro parte), pl. 18, fig. 5.

Elamena minuta - Kemp 1917: 250. - Tesch 1918: 21 (pro parte).

Halicarcinus minutus - Takeda \& Nunomura 1976: 65, fig. 2. - Lucas 1980: 177 (pro parte). Chuang \& Ng 1994: 88 (pro parte).

Micas minutus - Ng \& Richer de Forges 1996: 265-269, fig. 3. — Poore et al. 2016: 496.

This New Caledonian species has been collected under rocks in intertidal zone, along the shore or on the fringing reef of small coral islands.

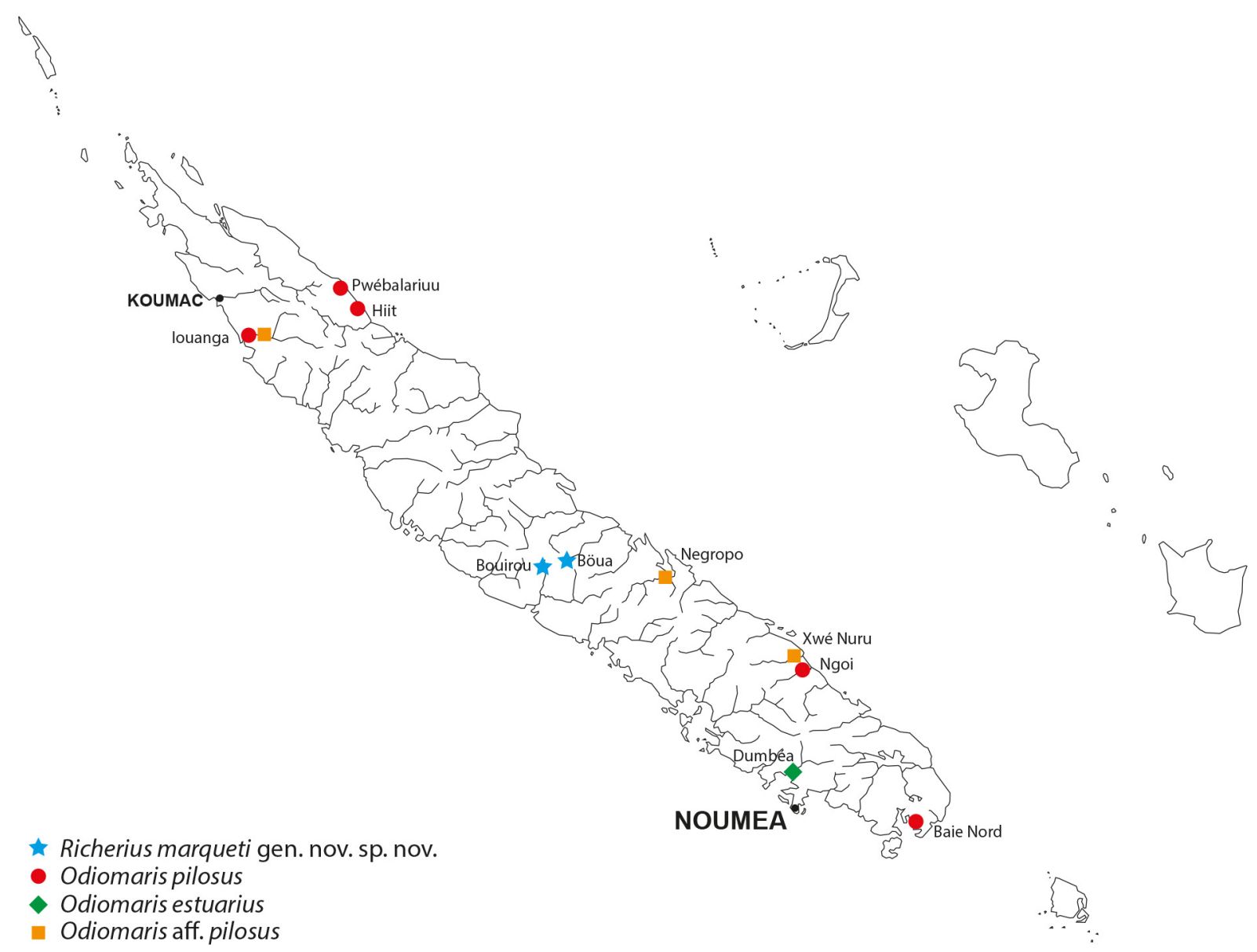

Fig. 10. Map of New Caledonia, showing localities where Richerius marqueti gen. et sp. nov., Odiomaris pilosus A. Milne-Edwards, 1873, Odiomaris estuarius Davie \& Richer de Forges, 1996 and Odiomaris aff. pilosus were collected. 
Genus Elamena H. Mine-Edwards, 1837

Type species by monotypy: Hymenosoma mathaei Desmarest, 1823.

The genus Elamena, which, with 24 species, is one of the most species-rich in the family Hymenosomatidae, can be separated into two groups (Lucas 1980). Elamena vesca is included in the group with a truncated rostrum and a polygonal carapace (Rahayu \& Nugroho 2019).

Elamena vesca $\mathrm{Ng} \&$ Richer de Forges, 1996

Elamene [sic] truncata A. Milne-Edwards, 1873: 323 (junior homonym of Trigonoplax truncata Stimpson, 1858).

Elamena vesca $\mathrm{Ng}$ \& Richer de Forges, 1996: 273, fig. 8.

Alphonse Milne-Edwards (1873) established Elamene [sic] truncata without giving figures and probably not aware of the existence of the Trigonoplax truncata of Stimpson (1858) from Japan. According to Kemp (1917), these similar specific names are due to coincidence. The two species are in fact different, and a new name, E. vesca, was created by $\mathrm{Ng} \&$ Richer de Forges (1996) using fresh specimens from New Caledonia as holotype and paratypes. The species is cryptic, intertidal on rocky shores, in shallow waters (about $0.5 \mathrm{~m}$ ).

\section{Discussion}

The new hymenosomatid Richerius marqueti gen. et sp. nov., found in two streams at altitudes of 180 $\mathrm{m}$ and $500 \mathrm{~m}$ in the inland waters of New Caledonia, is distinguished from the long-established taxon Odiomaris pilosus (with which it had been confused in the collections), which is also freshwater (but usually encountered in the lower course of rivers of New Caledonia) and euryhaline. Richerius gen. nov. differs from Amarinus, and in particular from its type species A. lacustris, reported from New Zealand freshwaters at altitudes of 61-92 $\mathrm{m}$ and even about 800-900 m a.s.l. Amarinus, which comprises many freshwater species of New Zealand, Australia, Indonesia, the Philippines and Papua New Guinea, is for the moment not known from New Caledonia. Another species (Odiomaris aff. pilosus) previously identified as Odiomaris pilosus, collected close to the sea in the Iouanga River and in other streams of the North Province and South Province, does not correspond to this species or to Richerius marqueti gen. et sp. nov. either; nor is it identifiable with the brackish representative of the genus, Odiomaris estuarius. DNA sequences of all these species that are in preparation hopefully will provide satisfactory answers to outstanding questions.

The carcinological fauna of New Caledonia, which does not host any of the exclusively primarily freshwater families, includes secondary freshwater species from primarily marine hymenosomatid stock, euryhaline species and strictly marine species. Our updated review lists seven genera: Richerius gen. nov., exclusively freshwater; Odiomaris, endemic, with a freshwater and euryhaline species, O. pilosus, and one brackish species, O. estuarius; Neorhynchoplax, with N. euryrostris, estuarine to tidal freshwater; Lucascinus, with L. keijibabai, from intertidal reef and perhaps endemic to New Caledonia; Micas, endemic, with two species: M. falcipes, from shallow reef, and M. minutus, from the intertidal zone or fringing reef; Elamenopsis, with E. lineata, an estuarine species, found in sandy mud, and in mangrove area; and Elamena, with $E$. vesca, cryptic, intertidal, in shallow waters. Other newly collected marine species, in study, will soon increase our knowledge of New Caledonian hymenosomatid fauna.

\section{Acknowledgements}

The New Caledonia Hydrobiological expeditions 2016-2018 (PI: Philippe Bouchet, who is here thanked profusely) are part of a cluster of expeditions under the 'Our Planet Reviewed/La Planète revisitée' 
programme, implemented by the Muséum national d'histoire naturelle (MNHN; Pascale Joannot, Head of expeditions programme) in partnership with the Conservatoire d'Espaces naturels (CEN), with funding from the Gouvernement de la Nouvelle-Calédonie, Province Sud, Province Nord, Office des Postes et Télécommunications (OPT), Maison de la Nouvelle-Calédonie, and the Ministère des Outre-mer (French Ministry for the Overseas). The expeditions operated under permits issued by the Province Sud (under APA_NCPS_2017_028) and Province Nord, and the organizers thank, respectively, Emmanuel Couture and Isabelle Jurquet (Province Sud) and Jean-Jérôme Cassan and Yannick Monlouis (Province Nord) for their help in issuing these permits. For logistics before, during and after the field work, we thank Sébastien Faninoz and Alice Leblond. Following research expeditions to the Forgotten Coast (in 2016), the landlocked Katalupatik massif in the North Province (in 2017), inland water systems in the Main Island (since 2016), and the Koumac lagoons and reefs (in September 2016), Our Planet Reviewed teams returned in 2019-2020 to continue the exploratory operations in New Caledonia.

The authors would like to thank Damien Grima (Province Sud) and Jean-Jérôme Cassan (Province Nord) for obtaining the collecting permits during the expedition of September 2016 jointly funded by the 'Observatoire de l'Environnement en Nouvelle Calédonie' and the government of the South Province; Gérard Marquet and Pascal Tiberghien for their help in the sampling during the same expedition, and Nicolas Charpin and the association "Vies d'Ô douce" (http://viesdodouce.com) for his help on the field during the Hydrobio expeditions of "Our Planet Reviewed" in November 2016 and November 2017, for providing additional specimens, and for kindly allowing us to use some of his pictures.

The authors express their profound thanks to Jean-François Dejouannet (MNHN, UMS2700-2AD, Atelier Iconographie scientifique) for all the sketches and photographs carefully prepared for the present paper: his invaluable contribution makes this work sound and comprehensive.

The authors are grateful to the two reviewers for their helpful comments to the manuscript.

\section{References}

Alcock A. 1900. Materials for a carcinological fauna of India. No. 6. The Brachyura Catometopa, or Grapsoidea. Journal of the Asiatic Society of Bengal 69 (2): 279-456. Available from

https://www.biodiversitylibrary.org/part/243394\#/summary [accessed 7 Jun. 2020].

Ali M.H., Salman S.D. \& Al-Adhub A.-H.Y. 1995. Population dynamics of the hymenosomatid crab Elamenopsis kempi in a brackish subtidal region of Basrah, Iraq. Scientia Marina 59 (1): 1-13. Available from http://scimar.icm.csic.es/scimar/index.php/secId/7/IdArt/2709/ [accessed 27 May 2020].

Ali M.H., Salman S.D. \& Al-Adhub A.-H.Y. 2000. Oxygen consumption of the freshwater crab Elamenopsis kempi (Chopra and Das, 1930) from the Garmat-Ali river, Iraq. Scientia Marina 64 (3): 311-317. https://doi.org/10.3989/scimar.2000.64n3311

Barnard K.H. 1950. Descriptive catalogue of South African decapod Crustacea. Annals of the South African Museum 38: 1-837. Available from https://decapoda.nhm.org/pdfs/38994/38994.pdf [accessed 27 May 2020].

Chilton C. 1915. A freshwater crab and its distribution in Australia and New Zealand. Transactions and Proceedings of the New Zealand Institute 47: 316-320. Available from http://rsnz.natlib.govt.nz/volume/rsnz_47/rsnz_47_00_005860.html [accessed 27 May 2020].

Chopra B. \& Das K.N. 1930. Further notes on Crustacea Decapoda in the Indian museum. I. On two new species of hymenosomatid crabs, with notes on some other species. Records of the Indian Museum 32 (4): 413-429. 
Chuang C.T.N. \& Ng P.K.L. 1994. The ecology and biology of Southeast Asian false spider crabs (Crustacea: Decapoda: Brachyura: Hymenosomatidae). In: Sasekumar A., Marshall N. \& Macintosh D.J. (eds) Ecology and Conservation of Southeast Asian Marine and Freshwater Environments including Wetlands. Hydrobiologia 285: 85-92. https://doi.org/10.1007/BF00005656

Davie P.J.F. \& Guinot D. 1996. Two new freshwater crabs in Australocarcinus Davie, with remarks on Trogloplacinae Guinot and Goneplacidae MacLeay. Memoirs of the Queensland Museum 39 (2): 277-287.

Davie P.J.F. \& Richer de Forges B. 1996. Two new species of hymenosomatid crabs from New Caledonia. Memoirs of the Queensland Museum 39 (2): 257-262.

Davie P.J.F., Guinot D. \& Ng P.K.L. 2015a. Anatomy and functional morphology of Brachyura. In: Castro P., Davie P.J.F., Guinot D., Schram F.R. \& Von Vaupel Klein J.C. (eds) Decapoda: Brachyura, Treatise on Zoology - Anatomy, Taxonomy, Biology. Vol. 9C-1, Chapter 71-2: 11-163. Brill, Leiden/ Boston. https://doi.org/10.1163/9789004190832_004

Davie P.J.F., Guinot D. \& Ng P.K.L. 2015b. Systematics and classification of Brachyura. In: Castro P., Davie P.J.F., Guinot D., Schram F.R. \& Von Vaupel Klein J.C. (eds) Decapoda: Brachyura, Treatise on Zoology - Anatomy, Taxonomy, Biology. Vol. 9C-2, Chapter 71-18: 1049-1130. Brill, Leiden/Boston. https://doi.org/10.1163/9789004190832_021

Dornelas M., Paula J. \& Macia A. 2003. The larval development of Hymenosoma orbiculare Desmarest, 1825 (Crustacea: Decapoda: Brachyura). Journal of Natural History 37 (21): 2579-2597.

https://doi.org/10.1080/00222930210155684

Etheridge R. 1889. The general zoology of Lord Howe Island; containing also an account of the collections made by the Australian Museum Collecting Party, Aug.-Sept., 1887. Australian Museum Memoir 2 (1): 1-4. https://doi.org/10.3853/j.0067-1967.2.1889.479

Folmer O., Black M., Hoeh W., Lutz R. \& Vrijenhoek R. 1994. DNA primers for amplification of mitochondrial cytochrome c oxidase subunit I from diverse metazoan invertebrates. Molecular Marine Biology and Biotechnology 3 (5): 294-299. Available from https://www.mbari.org/wp-content/uploads/2016/01/Folmer_94MMBB.pdf [accessed 7 Jun. 2020].

Fransen C.H.J.M., Holthuis L.B. \& Adema J.P.H.M. 1997. Type-Catalogue of the Decapod Crustacea in the collections of the Nationaal Natuurhistorisch Museum, with appendices of pre-1900 collectors and material. Zoologische Verhandlingen 311: i-xvi, 1-344. Available from https://www.repository.naturalis.nl/record/317736 [accessed 27 May 2020].

Fukuda Y. 1981. Larval development of Trigonoplax unguiformis (de Haan) (Crustacea Brachyura) reared in the Laboratory. Zoological Magazine (Tokyo) 90 (2): 164-173.

Grandcolas P., Murienne J., Robillard T., Desutter-Grandcolas L., Jourdan H., Guilbert E. \& Deharveng L. 2008. New Caledonia: a very old Darwinian island? Philosophical Transactions of the Royal Society B. Biological Sciences 363: 3309-3317. https://doi.org/10.1098/rstb.2008.0122

Guinot D. 2011a. Odiomarinae nov. subfam., a new subfamily for two primitive genera of the Hymenosomatidae MacLeay, 1838 (Crustacea, Decapoda, Brachyura). Zootaxa 2732: 20-32. https://doi.org/10.11646/zootaxa.2732.1.2

Guinot D. 2011b. The position of the Hymenosomatidae MacLeay, 1838, within the Brachyura (Crustacea, Decapoda). Zootaxa 2890: 40-52. https://doi.org/10.11646/zootaxa.2890.1.4

Guinot D. \& Richer de Forges B. 1997. Affinités entre les Hymenosomatidae MacLeay, 1838 et les Inachoididae Dana, 1851 (Crustacea, Decapoda, Brachyura). Zoosystema 19 (2-3): 453-502. Available from http://sciencepress.mnhn.fr/en/periodiques/zoosystema/19/23/ [accessed 27 May 2020]. 
Holthuis L.B. 1968. On Hymenosomatidae (Crustacea Decapoda Brachyura) from fresh water, with the description of a new species. Beaufortia 15 (195): 109-121. Available from https://www.repository.naturalis.n1/record/504776 [accessed 27 May 2020].

Holthuis L.B. 1982. Freshwater Crustacea Decapoda of New Guinea. In: Gressitt J.L. (ed.) Biogeography and Ecology of New Guinea. Vol. 2, Pt. 6. Monographiae Biologicae 42: 603-619.

https://doi.org/10.1007/978-94-009-8632-9_28

Hsueh P.-W. 2018. A new species of Neorhynchoplax (Crustacea: Decapoda: Brachyura: Hymenosomatidae) from Taiwan. Zootaxa 4461 (3): 350-358. https://doi.org/10.11646/zootaxa.4464.3.2

Jamieson B.G.M. \& Tudge C.C. 2000. Crustacea-Decapoda. In: Adiyodi K.G. \& Adiyodi R.G. (ser. eds), Jamieson B.G.M. (vol. ed.) Reproductive Biology of Invertebrates. Volume IX, Part C. Progress in Male Gamete Ultrastructure and Phylogeny. John Wiley and Sons. Chichester: 1-95.

Juncker M. \& Poupin J. 2009. Crustacés de Nouvelle-Calédonie (Décapodes \& Stomatopodes). Illustration des espèces communes et liste documentée des espèces terrestres et des récifs. Rapport Scientifique du CRISP (Coral Reef Initiative for the South Pacific). Available from poupin.joseph.free.fr/pdf/juncker-poupin-2009-crustaces-caledonie.pdf [accessed 27 May 2020].

Kearse M., Moir R., Wilson A., Stones-Havas S., Cheung M., Sturrock S., Buxton S., Cooper A., Markowitz S., Duran C., Thierer T., Ashton B., Meintjes P. \& Drummond A. 2012. Geneious Basic: an integrated and extendable desktop software platform for the organization and analysis of sequence data. Bioinformatics 28 (12): 1647-1649. https://doi.org/10.1093/bioinformatics/bts199

Kemp S. 1917. Notes on Crustacea Decapoda in the Indian Museum. X. Hymenosomatidae. Records of the Indian Museum 13: 243-279. https://doi.org/10.5962/bhl.part.5861

Komai T. \& Poore G.C.B. 2016. Resurrection of Rhynchoplax Stimpson, 1858, with the description of two new species from Japan and Australia (Crustacea: Decapoda: Brachyura: Hymenosomatidae). Zootaxa 4093 (4): 515-524. https://doi.org/10.11646/zootaxa.4093.4.3

Krishnan T. \& Kannupandi T. 1988. Larval development of Elamena (Trigonoplax) cimex Kemp, 1915 in the laboratory: the most unusual larvae known in the Brachyura (Crustacea: Decapoda). Bulletin of Marine Science 43 (2): 215-228. Available from

https://www.ingentaconnect.com/contentone/umrsmas/bullmar/1988/00000043/00000002/art00003 [accessed 7 Jun. 2020].

Lucas J.S 1971. The larval stages of some australian species of Halicarcinus (Crustacea, Brachyura, Hymenosomatidae). I. Morphology. Bulletin of Marine Science 21 (2): 471-490. Available from https://www.ingentaconnect.com/content/umrsmas/bullmar/1971/00000021/00000002/art00005 [accessed 7 Jun. 2020]

Lucas J.S. 1980. Spider crabs of the family Hymenosomatidae (Crustacea: Brachyura) with particular reference to Australian species: systematics and biology. Records of the Australian Museum 33 (4): 148-247. https://doi.org/10.3853/j.0067-1975.33.1980.199

Lucas J.S. \& Davie P.J.F. 1982. Hymenosomatid crabs of Queensland estuaries and tidal mud flats, including descriptions of four new species of Elamenopsis A. Milne-Edwards and a new species of Amarinus Lucas. Memoirs of the Queensland Museum 20 (3): 401-419. Available from https://www.biodiversitylibrary.org/part/218371\#/summary [accessed 27 May 2020].

Marquet G., Keith P. \& Vigneux E. 2003. Atlas des poissons et des crustacés d'eau douce de NouvelleCalédonie. Patrimoines naturels 58: 1-282. 
Naruse T., Ng P.K.L. \& Guinot D. 2008a. Two new genera and two new species of troglobitic false spider crabs (Crustacea: Decapoda: Brachyura: Hymenosomatidae) from Indonesia, with notes on Cancrocaeca Ng, 1991. Zootaxa 1739: 21-40. https://doi.org/10.11646/zootaxa.1739.1.2

Naruse T., Mendoza J.C.E. \& Ng P.K.L. 2008b. Descriptions of five new species of false spider crabs (Decapoda: Brachyura: Hymenosomatidae) from the Philippines. Marine Biology Research 4: 429-441. https://doi.org/10.1080/17451000802232866

Ng P.K.L. 1991. Cancrocaeca xenomorpha, new genus and species, a blind troglobitic freshwater hymenosomatid (Crustacea: Decapoda: Brachyura) from Sulawesi, Indonesia. Raffles Bulletin of Zoology 39 (1): 59-73. Available from

https://kcnhm.nus.edu.sg/app/uploads/2017/06/39rbz059-073.pdf [accessed 27 May 2020].

Ng P.K.L. \& Chuang C.T.N. 1996 The Hymenosomatidae (Crustacea: Decapoda: Brachyura) of Southeast Asia, with notes on other species. Raffles Bulletin of Zoology Supplement 3: 1-82. Available from https://decapoda.nhm.org/pdfs/12225/12225.pdf [accessed 27 May 2020].

Ng P.K.L. \& Richer de Forges B. 1996. The Hymenosomatidae (Crustacea: Decapoda: Brachyura) of New Caledonia, with descriptions of two new genera and two new species. Memoirs of the Queensland Museum 39(2): 263-276. Available from https://www.biodiversitylibrary.org/part/50813\#/summary [accessed 27 May 2020].

Ng P.K.L. \& Richer de Forges B. 2007. The Brachyura of New Caledonia. In: Payri C.E. \& Richer de Forges B. (eds) Compendium of Marine Species of New Caledonia: 315-331. Documents scientifiques et techniques, II7, seconde édition. IRD, Nouméa.

Ng P.K.L., Chen H.-L. \& Fang S.-H. 1999. On some species of Hymenosomatidae (Crustacea: Decapoda: Brachyura) from China, with description of a new species of Elamena and a key to the Chinese species. Journal of the Taiwan Museum 52 (1): 81-93.

Ng P.K.L., Guinot D. \& Davie P.J.F. 2008. Systema Brachyurorum: Part 1. An annotated checklist of extant brachyuran crabs of the world. Raffles Bulletin of Zoology Supplement 17: 1-286.

Ng P.K.L., Nesemann H.F. \& Sharma G. 2011. A new freshwater species of Neorhynchoplax Sakai, 1938 (Crustacea: Decapoda: Hymenosomatidae) from Patna, Bihar, India. Zootaxa 3063: 53-63. https://doi.org/10.11646/zootaxa.3063.1.4

Poore G.C.B. 2004. Marine Decapod Crustacea of Southern Australia. A Guide to Identification. CSIRO Publishing, Collingwood, Melbourne.

Poore G.C.B, Guinot D., Komai T. \& Naruse T. 2016. Reappraisal of species attributed to Halicarcinus (Crustacea: Decapoda: Brachyura: Hymenosomatidae) with diagnosis of four new genera and one new species from New Ireland, Papua New Guinea. Zootaxa 4093: 480-514.

https://doi.org/10.11646/zootaxa.4093.4.2

Poupin J. 2010. Biodiversité de l'Indo-Pacifique tropical français: 2514 espèces de crustacés décapodes et stomatopodes. Rapport scientifique Institut de Recherche de l'Ecole Navale: 1-70. Available from https://hal.archives-ouvertes.fr/hal-01559225/document [accessed 27 May 2020].

Rabalais N.N. \& Gore R.H. 1985. Abbreviated development in decapods. In: Wenner A.M. (ed.) Larval Growth. Crustacean Issues 2: 67-126. https://doi.org/10.1201/9781315140698

Rahayu D.L. \& Ng P.K.L. 2019. A new species of Elamenopsis from Papua, Indonesia (Decapoda, Brachyura, Hymenosomatidae). Crustaceana 92 (5): 537-544. https://doi.org/10.1163/15685403-00003883 Rahayu D.L \& Nugroho D.A. 2019. Three new species of the genus Elamena H. Milne-Edwards, 1837 (Crustacea: Decapoda: Hymenosomatidae) from Lombok Island, Indonesia. Raffles Bulletin of Zoology 67: 171-182. https://doi.org/10.26107/RBZ-2019-0014 
Rahayu D.L., Jayachandran P.R., Jima M., Bijoy Nandan S., Hershey N.R. \& Prabhakaran M.P. 2020. Notes on Neorhynchoplax alcocki (Kemp 1917) and Neorhynchoplax demeloi (Kemp 1917) from the Kochi Backwater, India (Crustacea: Decapoda: Brachyura: Hymenosomatidae). Thalassas 36: 79-84. https://doi.org/10.1007/s41208-019-00176-w

RiceA.L. 1980. Crab zoeal morphology and its bearing on the classification of the Brachyura. Transactions of the Zoological Society of London 35: 271-372. https://doi.org/10.1111/j.1096-3642.1980.tb00060.x

Rice A.L. 1981a. Crab zoeae and brachyuran classification: a re-appraisal. Bulletin of the British Museum of Natural History 40 (5): 287-296. https://www.biodiversitylibrary.org/part/35968

Rice A.L. 1981b. The megalopa stage in brachyuran crabs. The Podotremata Guinot. Journal of Natural History 15: 1003-1011. https://doi.org/10.1080/00222938100770751

Rice A.L. 1983. Zoeal evidence for brachyuran phylogeny. In: Schram F.R. (ed.) Crustacean Phylogeny. Crustacean Issues 1: 313-329.

Richer de Forges B. 1993. Deep sea crabs of the Tasman seamounts (Crustacea: Decapoda: Brachyura). Records of the Australian Museum 45 (1): 12-13. https://doi.org/10.3853/j.0067-1975.45.1993.126

Richer de Forges B., Jamieson B.G.M., Guinot D. \& Tudge C.C. 1997. Ultrastructure of the spermatozoa of Hymenosomatidae (Crustacea: Brachyura) and the relationships of the family. Marine Biology 130: 233-242. https://doi.org/10.1007/s002270050243

Serène R. \& Umali A.F. 1970. The family Raninidae and other new species of brachyuran decapods from the Philippines and adjacent regions. Philippine Journal of Science 99 (1/2): 21-105.

Shen C.-J. 1932. The Brachyuran Crustacea of North China. Zoologica Sinica, Series A. Invertebrates of China 9 (1): $\mathrm{i}-\mathrm{x}+1-321$.

Stimpson W. 1858. Prodromus descriptionis animalium evertebratorum, quae in Expeditione ad Oceanum Pacificum Septentrionalem, a Republica Federate missa, Cadwaladaro Ringgold et Johanne Rodgers Ducibus, observatit et descripsit. V. Crustacea Ocypodoidea. Proceedings of the Academy of Natural Sciences of Philadelphia 10: 93-110. Available from https://repository.si.edu/handle/10088/34394 [accessed 27 May 2020].

Takeda M. \& Miyake S. 1971. A new freshwater crab of the family Hymenosomatidae from the Palau Islands. Researches on Crustacea 4-5: 157-163. https://doi.org/10.18353/rcustacea.4.5.0_157

Takeda M. \& Nunomura N. 1976. Crabs collected by the Melanesia Expedition of the Osaka Museum of Natural History, 1958. Bulletin of the Osaka Museum of Natural History 30: 61-92.

Tesch J.J. 1918. The Decapoda Brachyura of the Siboga Expedition. I. Hymenosomidae, Retroplumidae, Ocypodidae, Grapsidae and Gecarcinidae. Siboga Expeditie 39c (livr. 82): 1-148. Available from https://www.biodiversitylibrary.org/item/18455\#page/7/mode/1up [accessed 27 May 2020].

Tudge C.C, Scheltinga D.M., Jamieson B.G.M., Guinot D. \& Richer de Forges B. 2014. Comparative ultrastructure of the spermatozoa of the Majoidea (Crustacea, Decapoda, Brachyura) with new data on six species in five genera. Acta Zoologica 95: 1-20. https://doi.org/10.1111/azo.12005

Wear R.G. \& Fielder D.R. 1985. The marine fauna of New Zealand: larvae of the Brachyura (Crustacea Decapoda). Memoirs of the New Zealand Oceanographic Institute 92: 1-90. Available from https://archive.org/details/nzoimemoir00921985 [accessed 27 May 2020].

Yeo D.C.J., Ng P.K.L., Cumberlidge N., Magalhães C., Daniels S.R. \& Campos M.R. 2008. Global diversity of crabs (Crustacea: Decapoda: Brachyura) in freshwater. In: Balian E.V., Lévêque C., Segers H. \& Martens K. (eds) Freshwater Animal Diversity Assessment. Hydrobiologia 595: 275-286. https://doi.org/10.1007/s10750-007-9023-3 
Manuscript received: 27 February 2020

Manuscript accepted: 23 April 2020

Published on: 22 June 2020

Topic editor: Rudy Jocqué

Desk editor: Pepe Fernández

Printed versions of all papers are also deposited in the libraries of the institutes that are members of the EJT consortium: Muséum national d'histoire naturelle, Paris, France; Meise Botanic Garden, Belgium; Royal Museum for Central Africa, Tervuren, Belgium; Royal Belgian Institute of Natural Sciences, Brussels, Belgium; Natural History Museum of Denmark, Copenhagen, Denmark; Naturalis Biodiversity Center, Leiden, the Netherlands; Museo Nacional de Ciencias Naturales-CSIC, Madrid, Spain; Real Jardín Botánico de Madrid CSIC, Spain; Zoological Research Museum Alexander Koenig, Bonn, Germany; National Museum, Prague, Czech Republic. 